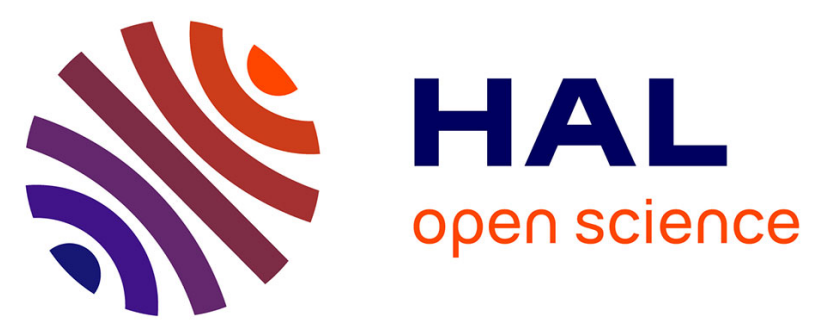

\title{
Thorium and protactinium isotopes as tracers of marine particle fluxes and deep water circulation in the Mediterranean Sea
}

Sandra Gdaniec, Matthieu Roy-Barman, Lorna Foliot, François Thil, Arnaud Dapoigny, Pierre Burckel, Jordi Garcia-Orellana, Pere Masqué, Carl-Magnus

Mörth, Per Andersson

\section{To cite this version:}

Sandra Gdaniec, Matthieu Roy-Barman, Lorna Foliot, François Thil, Arnaud Dapoigny, et al.. Thorium and protactinium isotopes as tracers of marine particle fluxes and deep water circulation in the Mediterranean Sea. Marine Chemistry, 2018, 199, pp.12-23. 10.1016/j.marchem.2017.12.002 . hal-02467753

\section{HAL Id: hal-02467753 https://hal.science/hal-02467753}

Submitted on 24 Jun 2021

HAL is a multi-disciplinary open access archive for the deposit and dissemination of scientific research documents, whether they are published or not. The documents may come from teaching and research institutions in France or abroad, or from public or private research centers.
L'archive ouverte pluridisciplinaire HAL, est destinée au dépôt et à la diffusion de documents scientifiques de niveau recherche, publiés ou non, émanant des établissements d'enseignement et de recherche français ou étrangers, des laboratoires publics ou privés. 


\title{
Thorium and Protactinium isotopes as tracers of marine particle fluxes and deep water circulation in the Mediterranean Sea
}

\author{
Sandra Gdaniec ${ }^{\mathrm{a}, \mathrm{b}, \mathrm{c}}$, Matthieu Roy-Barman ${ }^{\mathrm{c}}$, Lorna Foliot ${ }^{\mathrm{c}}$, Francois Thil ${ }^{\mathrm{c}}$, Arnaud \\ Dapoigny $^{c}$, Pierre Burckel ${ }^{c}$, Jordi Garcia-Orellana ${ }^{d}$, Pere Masqué ${ }^{d, e, f}$, Carl-Magnus Mörth $^{a}$ \\ and Per S. Andersson ${ }^{\mathrm{b}}$ \\ ${ }^{a}$ Stockholm University, Department of Geological sciences, Stockholm, Sweden \\ ${ }^{\mathrm{b}}$ Swedish Museum of Natural History, Department of Geosciences, Stockholm, Sweden \\ ${ }^{\mathrm{C}}$ Laboratoire des Sciences du Climat et de I'Environnement, LSCE/IPSL, CEA-CNRS-UVSQ, \\ Université Paris-Saclay,Gif-sur-Yvette, France \\ ${ }^{\mathrm{d}}$ Institut de Ciència i Tecnologia Ambientals \& Departament de Física, Universitat Autònoma de \\ Barcelona, Bellaterra 08193, Spain \\ ${ }^{\text {e}}$ School of Science, Centre for Marine Ecosystems Research, Edith Cowan University, Joondalup, WA \\ 6027, Australia \\ ${ }^{\dagger}$ Oceans Institute and School of Physics, University of Western Australia, 35 Stirling Highway, \\ Crawley, WA 6009, Australia
}

\section{Corresponding author:}

Sandra Gdaniec

Sandra.gdaniec@nrm.se

Swedish Museum of Natural History

Svante Ahrenius väg 3

11418 Stockholm

Sweden

\section{E-mails:}

Matthieu Roy-Barman: matthieu.roy-barman@lsce.ipsl.fr

Lorna Foliot: lorna.foliot@Isce.ipsl.fr

Francois Thil: francois.thil@Isce.ipsl.fr

Arnaud Dapoigny: arnaud.dapoigny@lsce.ipsl.fr

Pierre Burckel: pierre.burckel@lsce.ipsl.fr

Jordi Garcia-Orellana: jordi.garcia@uab.cat

Pere Masque: pere.masque@uab.cat

Carl-Magnus Mörth: magnus.morth@su.se

Per S. Andersson: per.andersson@nrm.se 


\section{Abstract}

${ }^{231} \mathrm{~Pa},{ }^{230} \mathrm{Th}$ and ${ }^{232} \mathrm{Th}$ were analyzed in unfiltered seawater samples $(\mathrm{n}=66)$ and suspended particles $(n=19)$ collected in the Mediterranean Sea during the MedSeAGA04-S cruise along the GEOTRACES section GA04S and used to investigate mechanisms controlling the distribution and fractionation of $\mathrm{Pa}$ and $\mathrm{Th}$ in an ocean margin environment. ${ }^{231} \mathrm{~Pa}$ and ${ }^{230} \mathrm{Th}$ are particle reactive radionuclides and are often used as tracers of processes such as boundary scavenging, particle transport and ocean circulation. The depth profiles of total ${ }^{231} \mathrm{~Pa}$ and ${ }^{230} \mathrm{Th}$ concentrations in the Mediterranean Sea displayed non-linear shapes. Higher total ${ }^{232} \mathrm{Th}$ concentrations were observed at the straits and in deep waters pointing at lithogenic sources. Fractionation factors $F_{T h / P a}$ ranged from 1.4 to 9 . Application of a box-model illustrated that $94 \%$ of the ${ }^{231} \mathrm{~Pa}$ and almost all of the ${ }^{230} \mathrm{Th}(99.9 \%)$ produced in the Mediterranean Sea is removed to the sediment by scavenging. The negligible export of ${ }^{230} \mathrm{Th}$ to the Atlantic Ocean, leads to a reevaluation of the mean settling speed of the filtered particles, which is now estimated to $500-1000 \mathrm{~m} / \mathrm{y}$. The low $\mathrm{F}_{\mathrm{Th} / \mathrm{Pa}}$ fractionation factors are attributed to the efficient scavenging and lack of transport of ${ }^{231} \mathrm{~Pa}$ to the Atlantic Ocean. 


\section{Introduction}

Particle dynamics in oceanic systems impact global biogeochemical cycles (e.g. Buesseler et al., 2007; Martin et al., 1987; Miquel et al., 1994). Marine particles are important regulators of ocean chemistry as they determine the residence time of many bioavailable dissolved elements (e.g. Fe, Mn, Mg) in seawater (Jeandel et al., 2015). In particular, the vertical and horizontal distribution of many trace elements is influenced by particle formation, remineralization and transport (e.g. Jeandel et al., 2015; Lal, 1977).

Protactinium and thorium are important tracers for marine particles and deep water circulation (Bacon, 2005; Roy-Barman et al., 2009; Rutgers van der Loeff and Berger, 1993). ${ }^{231} \mathrm{~Pa}\left(\mathrm{t}_{1 / 2}=32760 \mathrm{y}\right)$ and ${ }^{230} \mathrm{Th}\left(\mathrm{t}_{1 / 2}=75690 \mathrm{y}\right)$ are natural radionuclides produced by the radioactive decay of ${ }^{235} \mathrm{U}$ and ${ }^{234} \mathrm{U}$, respectively. ${ }^{232} \mathrm{Th}$ is a primordial long-lived isotope and can be used as a fingerprint of recent lithogenic supply. In the open ocean, ${ }^{232}$ Th is likely to be dominantly supplied by the dissolution of dust (Hsieh et al., 2011). Pa and Th are particle reactive and are removed from the water column by scavenging onto settling particles. In the absence of lateral transport by currents, the vertical distribution of ${ }^{231} \mathrm{~Pa}$ and ${ }^{230} \mathrm{Th}$ in the water column is expected to increase linearly with depth, in which case, the particulate ${ }^{230} \mathrm{Th}$ distribution can be used to determine the average settling speed of the particulate matter (Bacon and Anderson, 1982). Deviations from a linear depth profile indicate that oceanic currents transport ${ }^{231} \mathrm{~Pa}$ and ${ }^{230} \mathrm{Th}$ away from the location where they were produced (Rutgers van der Loeff and Berger, 1993). This is the case during deep water formation (Roy-Barman et al., 2002) or when insoluble elements are advected towards and scavenged at ocean margins (RoyBarman, 2009). The removal at ocean margins (also called boundary scavenging) is important for many insoluble elements with long ocean residence times (>100 y). It is therefore valuable to separate the relative contribution of circulation and particle transport on the $\mathrm{Pa}$ and $\mathrm{Th}$ profiles. Th is more particle reactive compared to $\mathrm{Pa}$ (Anderson et al., 1983a; Anderson et al., 1983b). As a result, sediments are often depleted in ${ }^{231} \mathrm{~Pa}$ relative to ${ }^{230} \mathrm{Th}$ compared to their production ratio derived from the decay of uranium (e.g. Yu et al., 1996). Th is removed from the open ocean by adsorption onto settling particles and Pa primarily by lateral transport by currents to other environments such as ocean margins and opal-rich areas where sediments are enriched in ${ }^{231} \mathrm{~Pa}$ relative to ${ }^{230} \mathrm{Th}$ (Anderson et al., 1983a; Anderson et al., 1983b). Along the shelves and slopes, boundary scavenging plays a key role in the burial of ${ }^{231} \mathrm{~Pa}$, because particle fluxes in the open basins are small. 
There is an ongoing discussion regarding the use of ${ }^{231} \mathrm{~Pa} /{ }^{230} \mathrm{Th}$ ratios as a tracer of the past meridional overturning circulation (e.g. Deng et al., 2014; Lippold et al., 2012; Walter et al., 1997). Much of the debate concerns the processes controlling ${ }^{231} \mathrm{~Pa} /{ }^{230} \mathrm{Th}$ ratios in marine sediments, such as the intensity of thermohaline circulation, particle composition and particle fluxes (Hayes et al., 2015b; Siddall et al., 2005).

In this study, particulate and total ${ }^{231} \mathrm{~Pa},{ }^{230} \mathrm{Th}$ and ${ }^{232} \mathrm{Th}$ concentrations in depth profiles from the Mediterranean Sea are presented. The objective was to: (1) study the relative influence of scavenging and deep water ventilation on the vertical distribution of ${ }^{231} \mathrm{~Pa}$ and ${ }^{230} \mathrm{Th}$; (2) determine the relative affinity of $\mathrm{Pa}$ and $\mathrm{Th}$ for particles a closed sea environment and (3) to reevaluate the settling velocity of the particles in the Mediterranean Sea, with a particular care for possible bias linked to lateral transport.

\section{Hydrographic settings}

The Mediterranean Sea is composed of two main basins, the Western and the Eastern Basin separated by the Sicily strait (Fig. 1). The surface layer $(\sim 0-200 \mathrm{~m})$ in the Western Mediterranean Sea is dominated by Atlantic Water (AW), which becomes Modified Atlantic Water (MAW, S 35.9) along its path towards the Eastern Basin. In the Levantine Sea, the MAW sinks through surface heat loss and evaporation and transforms into Levantine Intermediate Water (LIW, S 39, depth range $\sim 200-600 \mathrm{~m}$ ) on its return to the Atlantic (Fig. 2).

Deep dense water formation is frequent over the shelf areas and in the open ocean regions, both in the Western and Eastern Mediterranean Basins (e.g. Castellari, 2000; Robinson et al., 1992). The Western Basin is characterized by a relatively short water residence time ( $\mathrm{T}_{\mathrm{w}}=\sim 15 \mathrm{y}$, Béthoux and Gentili, 1999) due to the almost annual occurrence of deep water formation near the Gulf of Lions and in the Ligurian Sea (Houpert et al., 2016; Millot, 1999). The Eastern Basin is characterized by longer water residence times ( $\mathrm{T}_{\mathrm{w}}=\sim 60 \mathrm{y}$, (Béthoux and Gentili, 1999). The deep waters within the Eastern Mediterranean Sea (EMDW) are formed in the southern Adriatic Sea (EMDW Adr $\left._{\text {r }}\right)$ and Aegean Sea $\left(E M D W_{A g}\right.$ ), which fills the lonian and Levantine Seas (El-Geziry and Bryden, 2010) (Fig. 2). There is a biological productivity gradient between the Western Basin, which is generally oligotrophic with mesotrophic conditions in spring in the Northern Algero-Balearic Basin, and the ultra-oligotrophic Eastern Basin (Boldrin et al., 2002; Pujo-Pay et al., 2011). 


\section{Methods}

\section{Sampling}

Samples were collected during the Mediterranean Sea Acidification in a Changing Climate cruise (MedSeA-GA04-S) onboard B/O Ángeles Alvariño between May and June 2013. Unfiltered seawater samples were collected at 10 stations distributed in the main basins along the GEOTRACES section GA04S (Fig. 1). Unfiltered seawater samples were collected in $12 \mathrm{~L}$ Niskin $\AA$ bottles mounted on a General Oceanic $₫$ rosette equipped with a Sea-Bird Electronics CTD system (SBE 911plus). The CTD system was equipped with sensors allowing measurements of salinity, temperature, oxygen, turbidity and density. For the analysis of $\mathrm{Pa}$ and $\mathrm{Th}, 5 \mathrm{~L}$ of seawater was subsampled from the $12 \mathrm{~L}$ Niskin bottles followed by acidification with ultrapure $\mathrm{HCl}$ to prevent Th and $\mathrm{Pa}$ sorption on the container walls.

Marine particles (from 6 stations) were collected by filtration onto nylon screens (Nitex, SEFAR, diameter $142 \mathrm{~mm}$ (pore size $1 \mu \mathrm{m}$ ) using in-situ pumps (Challenger type) (Fig. 1). An aliquot of the filter was cut out and used for trace metal analysis while the remaining fraction was resuspended and divided into 3 equal parts which were re-filtered onto Nucleopore® filters and stored until analysis. One of these fractions was dedicated for the analysis of $\mathrm{Pa}-\mathrm{Th}$ isotopes.

\section{Chemical preparation of $\mathrm{Pa}$ and $\mathrm{Th}$ in seawater and particulate samples}

The seawater samples were spiked with ${ }^{233} \mathrm{~Pa}$ and ${ }^{229} \mathrm{Th}$ followed by the addition of 20 $\mathrm{mg}$ of $\mathrm{Fe}$ from a $\mathrm{FeCl}_{3}$ solution. The ${ }^{233} \mathrm{~Pa}$ spike was calibrated using an "in-house" ${ }^{231} \mathrm{~Pa}$ standard solution measured over several years and calibrated against Harwell Uraninite (HU-1) which is used as a $U$ standard at secular equilibrium. After 1 day, the $\mathrm{pH}$ of the water was increased to $\mathrm{pH} 8-9$ by an addition of $\mathrm{NH}_{3}$ to produce $\mathrm{Fe}(\mathrm{OH})_{3}$. The iron precipitate was allowed to settle for $24 \mathrm{~h}$ and recovered by siphoning the overlying water followed by centrifugation. After centrifugation, the precipitate was dissolved in concentrated $\mathrm{HNO}_{3}$. As $\mathrm{Pa}$ has a strong affinity for amorphous silica precipitated from silicic acid, this must be removed during sample preparation. Amorphous silica was separated by centrifugation: the supernatant was removed and the residual silica gel was dissolved in a mixture of concentrated $\mathrm{HNO}_{3}$ and $\mathrm{HF}$. This solution was dried and redissolved in $8 \mathrm{~N} \mathrm{HNO}_{3}$ saturated with $\mathrm{H}_{3} \mathrm{BO}_{3}$, to prevent co-precipitation of Th with $\mathrm{CaF}_{2}$, followed by evaporation and redissolution in $8 \mathrm{~N} \mathrm{HNO}_{3}$. The resulting solution and the supernatant were mixed and passed through anionic ion exchange columns filled with Bio-Rad AG1-X8 anion exchange resin (i.e. 200-400 mesh) to obtain pure fractions 
of $\mathrm{Pa}$ and Th. The anionic column exchange procedure using a single column was adapted from Jeandel et al. (2011) to process smaller samples (Gdaniec et al. 2017, in preparation).

Particles collected with in-situ pumps were leached in $4 \mathrm{~N} \mathrm{HCl}$ solution at $50^{\circ} \mathrm{C}$ for $72 \mathrm{~h}$. The leachate was evaporated and dissolved in concentrated $\mathrm{HNO}_{3}$ followed by the $\mathrm{Si}$ dissolution procedure described above. After the Si-dissolution procedure, the two solutions were mixed, spiked with ${ }^{233} \mathrm{~Pa}$ and ${ }^{229} \mathrm{Th}$ and purified by letting the sample go through anionic ion exchange columns using the same procedure as for the seawater.

\section{Mass spectrometry}

$\mathrm{Pa}$ and Th were analyzed by Multiple Collector Inductively Coupled Plasma Mass Spectrometry (MC-ICP-MS) at Laboratoire des Sciences du Climat et de I'Environnement (LSCE) on a Thermo Scientific ${ }^{\mathrm{TM}}$ Neptune Plus ${ }^{\mathrm{TM}}$ instrument equipped with an Aridus $\mathrm{II}^{\mathrm{TM}}$ desolvator and a Jet interface following the protocols derived from Burckel et al. (2015). For the Th analysis, ${ }^{230} \mathrm{Th}$ and ${ }^{229} \mathrm{Th}$ were measured sequentially on the axial electron multiplier. Simultaneously, ${ }^{232} \mathrm{Th}$ was measured on off-axis faraday cups. A RPQ system was used to reduce the abundance sensitivity and half masses were measured around ${ }^{230} \mathrm{Th}$ for an accurate correction of the baseline. An $U$ standard solution was used to measure for the mass fractionation and the detector yield. A Th standard solution was used to measure the hydride contribution and abundance sensitivity. During the Th-analysis, standard solutions (IRMM-035, IRMM-036 and an "inhouse" standard) were measured to monitor the reproducibility of the Th measurements. For the $\mathrm{Pa}$ analysis, ${ }^{231} \mathrm{~Pa}$ and ${ }^{233} \mathrm{~Pa}$ were measured simultaneously on the non-axial electron multipliers. Simultaneously, ${ }^{232} \mathrm{Th}$ and ${ }^{235} \mathrm{U}$ and ${ }^{238} \mathrm{U}$ were measured on off-axis faraday cups to monitor abundance sensitivity and hydride contributions. An $U$ standard solution was used to measure for the mass fractionation and the detector yield. The tuning of the MC-ICP-MS was done by using an "in-house" mixed ${ }^{231} \mathrm{~Pa}^{-233} \mathrm{U}$ solution. This solution was also analyzed every fifth sample to bracket the samples and check the instrument's short and long-term drift and variability. Overall uncertainty was determined by applying corrections on the raw isotope ratios for the contribution of the mass bias, detector yield, abundance sensitivity and Th-hydride. Moreover, all measured ${ }^{231} \mathrm{~Pa}$ and ${ }^{230} \mathrm{Th}$ concentrations were corrected for the in-growth of ${ }^{231} \mathrm{~Pa}$ and ${ }^{230} \mathrm{Th}$ by uranium decay during the time period between sample collection (2013) and the U-Th/Pa separation (2014-2015). Uranium concentrations in the samples were estimated using the bottle salinity measured from the CTD and the U-Salinity relationship in seawater (U 
$=(0.100 * \mathrm{~S}-0.326)$, Owens et al., 2011). All uncertainties are expressed as 2 standard errors including the propagated contribution from sample weighting, spike calibration, impurities in spikes, blank corrections and mass spectrometric measurements.

The ${ }^{231} \mathrm{~Pa},{ }^{230} \mathrm{Th}$ and ${ }^{232} \mathrm{Th}$ concentrations in particles and seawater were corrected for blank contributions. Procedural blanks were determined by performing a complete chemical procedure on $250 \mathrm{ml}$ of Milli-Q® water with each batch of samples. Total procedural blanks for seawater samples ranged between $1.3 \mathrm{pg}$ and $14.8 \mathrm{pg}$ for ${ }^{232} \mathrm{Th}$ (average $=10 \pm 2.3 \mathrm{pg}$ ), 0.06 and $4 \mathrm{fg}$ for ${ }^{230} \mathrm{Th}$ (average $=2.4 \pm 0.7 \mathrm{fg}$ ) and 0.03 and $2.7 \mathrm{fg}$ for ${ }^{231} \mathrm{~Pa}$ (average $=1.2 \pm 0.2 \mathrm{fg}$ ). Total procedural blanks for particulate samples ranged between $4.6 \mathrm{pg}$ and $12 \mathrm{pg}$ for ${ }^{232} \mathrm{Th}$ (average $=6.4 \pm 3.2 \mathrm{pg}$ ), $0.02 \mathrm{fg}$ and $0.05 \mathrm{fg}$ for ${ }^{230} \mathrm{Th}$ (average $=0.05 \pm 0.03 \mathrm{fg}$ ) and $0.07 \mathrm{fg}$ and $0.23 \mathrm{fg}$ for ${ }^{231} \mathrm{~Pa}$ (average $=0.17 \pm 0.08 \mathrm{fg}$ ). These blanks were equivalent to $0.05-4 \%$ of the measured ${ }^{232} \mathrm{Th}, 0.6-20 \%$ of the measured ${ }^{230} \mathrm{Th}$ and $4-40 \%$ of the measured ${ }^{231} \mathrm{~Pa}$. The Th isotope analysis at LSCE was validated by the GEOTRACES intercalibration exercise (Anderson et al., 2012).

\section{Lithogenic corrections}

In order to determine the ${ }^{231} \mathrm{~Pa}$ and ${ }^{230} \mathrm{Th}$ concentrations derived exclusively from the insitu decay of $\mathrm{U}$-isotopes in seawater, the measured ${ }^{231} \mathrm{~Pa}$ and ${ }^{230} \mathrm{Th}$ concentrations were corrected for contributions from lithogenic material. The excess ${ }^{231} \mathrm{~Pa}_{\mathrm{xs}}$ and ${ }^{230} \mathrm{Th}_{\mathrm{xs}}$ were calculated using the following equations:

$$
\begin{aligned}
& { }^{230} T h_{x S}={ }^{230} T h_{m}-{ }^{232} T h_{m} \times\left(\frac{230 T h}{{ }^{232} T h}\right) \text { Litho } \\
& { }^{231} P a_{x s}={ }^{231} P a_{m}-{ }^{232} T h_{m} \times\left(\frac{230}{23 h}\right)_{L i t h o} \times\left(\frac{M_{231}}{M_{230}}\right) \times\left(\frac{\lambda_{230} \times \lambda_{235}}{\lambda_{238} \times \lambda_{231}}\right) \times\left(\frac{235}{238}\right)_{n a t}
\end{aligned}
$$

Where ${ }^{231} \mathrm{~Pa}_{\mathrm{x}}$ and ${ }^{230} \mathrm{Th}_{\mathrm{xs}}$ are the ${ }^{231} \mathrm{~Pa}$ and ${ }^{230} \mathrm{Th}$ produced solely from the in situ decay of ${ }^{235} \mathrm{U}$ and ${ }^{234} \mathrm{U}$ in seawater. The subscript $\mathrm{m}$ refers to the measured ${ }^{231} \mathrm{~Pa},{ }^{230} \mathrm{Th}$ and ${ }^{232} \mathrm{Th}$ concentrations in seawater and particles. The $\lambda_{230}, \lambda_{231}, \lambda_{235}$ and $\lambda_{238}$ are the decay constants for ${ }^{230} \mathrm{Th}\left(\lambda_{230}=9.16 \times 10^{-6} \mathrm{y}^{-1}\right.$, Cheng et al., 1998$),{ }^{231} \mathrm{~Pa}\left(\lambda_{231}=2.11 \times 10^{-5} \mathrm{y}^{-1}\right.$, Cheng et al., 1998), ${ }^{235} \mathrm{U}\left(\lambda_{235}=9.85 \times 10^{-10} \mathrm{y}^{-1}\right.$, Condon et al., 2010) and ${ }^{238} \mathrm{U}\left(\lambda_{238}=1.55\right.$ $\times 10^{-10} \mathrm{y}^{-1}$, Condon et al., 2010), respectively. The $\left({ }^{230} \mathrm{Th}{ }^{232} \mathrm{Th}\right)_{\text {Litho }}=4.0 \times 10^{-6} \mathrm{~mol} / \mathrm{mol}$ (close to average crust ${ }^{230} \mathrm{Th}^{232} \mathrm{Th}=4.3 \times 10^{-6} \mathrm{~mol} / \mathrm{mol}$ ) was based on sediment trap 
data from Roy-Barman et al. (2009), and the $\left({ }^{235} U{ }^{238} U_{\text {nat }}=1 / 137.88 \mathrm{~mol} / \mathrm{mol}\right)$ (Condon et al., 2010).

\section{Fractionation factor calculations}

The particle composition, the supply or removal by advection or scavenging affects the ${ }^{230} \mathrm{Th}_{\mathrm{xs}}{ }^{231} \mathrm{~Pa}_{\mathrm{xs}}$ ratios in seawater and particles. The differential scavenging of $\mathrm{Pa}$ and $\mathrm{Th}$ is estimated with the fractionation factor $\mathrm{F}_{\mathrm{Pa} / \mathrm{Th}}$ defined as (Anderson et al., 1983):

$$
F_{T h / P a}=\frac{\left.{ }^{230} T h_{x S} /{ }^{231} P a_{x s}\right) \text { particles }}{\left({ }^{230} T h_{x S} / /^{231} P a_{x s}\right) \text { seawater }}
$$

\section{Box-model calculations}

In order to estimate the amount of the in-situ produced $\mathrm{Pa}$ and Th scavenged within the Mediterranean Sea or transported to the Atlantic, a box-model was used to constrain ${ }^{231} \mathrm{~Pa}_{\mathrm{xs}}$ and ${ }^{230} \mathrm{Th}_{\mathrm{xs}}$ budgets. Net-fluxes at the straits were derived from the ${ }^{231} \mathrm{~Pa}_{\mathrm{xs}}$ and ${ }^{230} \mathrm{Th}_{\mathrm{xs}}$ concentration profiles from this study along with water fluxes from Béthoux and Gentili, (1999). These fluxes for the two basins were compared to the in-situ production of ${ }^{231} \mathrm{~Pa}_{\mathrm{xs}}$ and ${ }^{230} \mathrm{Th}_{\mathrm{xs}}$ for the two basins. The concentration of ${ }^{231} \mathrm{~Pa}_{\mathrm{xs}}$ and ${ }^{230} \mathrm{Th}_{\mathrm{xs}}$ used as inflowing and outflowing waters at the straits of Gibraltar and Sicily were determined using current velocity depth profiles at both straits (Beranger et al., 2004; Tsimplis, 2000) (Tab. 1). Net-fluxes and in-situ production rates of ${ }^{231} \mathrm{~Pa}_{\mathrm{xs}}$ and ${ }^{230} \mathrm{Th}_{\mathrm{xs}}$ were estimated using the equations summarized in Table S1.

For the Eastern Basin, the water fluxes in and out from Adriatic Sea and the Aegean Sea were not considered. Instead, the Eastern Basin box-model included the Aegean and Adriatic water masses. Therefore, the water fluxes considered were those in and out of the Eastern Basin through the Strait of Sicily. The fluxes in and out of the Black Sea are neglected (Bethoux and Gentilli, 1996).

\section{Results}

\section{${ }^{231} \mathrm{~Pa},{ }^{230} \mathrm{Th}$ and ${ }^{232} \mathrm{Th}$ in unfiltered seawater}

The total ${ }^{232} \mathrm{Th}$ concentrations in the water column ranged between $69 \mathrm{pg} / \mathrm{kg}$ and 876 $\mathrm{pg} / \mathrm{kg}$ and generally decrease with depth. Higher total ${ }^{232} \mathrm{Th}$ concentrations were observed in near surface waters of Sicily Strait and in the Alboran Sea. Higher 
concentrations of ${ }^{232} \mathrm{Th}$ were also found throughout the water column at the Strait of Gibraltar and at $2500 \mathrm{~m}$ depth in the Northern Algero-Balear (NABB) (Tab. S2, Fig. 3C).

Generally, higher concentrations of total ${ }^{230} \mathrm{Th}(1.7-9.8 \mathrm{fg} / \mathrm{kg})$ and ${ }^{231} \mathrm{~Pa}(0.09-$ $1.06 \mathrm{fg} / \mathrm{kg}$ ) were observed in the Eastern Basin, compared to concentrations of ${ }^{230} \mathrm{Th}$ (2.8-6.2 fg/kg) and ${ }^{231} \mathrm{~Pa}(0.16-0.9 \mathrm{fg} / \mathrm{kg})$ in the Western Basin (Tab. S2).

In the Eastern Basin, ${ }^{231} \mathrm{~Pa}_{\mathrm{xs}}$ concentrations ranged between $0.05 \mathrm{fg} / \mathrm{kg}$ and 1.04 fg/kg (Fig. 3A), while ${ }^{230} \mathrm{Th}_{\mathrm{xs}}$ concentrations ranged between $0.6 \mathrm{fg} / \mathrm{kg}$ and $9.4 \mathrm{fg} / \mathrm{kg}$ (Fig. 3B). In the Western Basin, the ${ }^{231} \mathrm{~Pa}_{\mathrm{xs}}$ concentrations ranged between $0.14 \mathrm{fg} / \mathrm{kg}$ to 0.89 fg/kg (Fig. $3 \mathrm{~A}$ ) and ${ }^{230} \mathrm{Th}_{\mathrm{xs}}$ concentrations ranged between $2.7 \mathrm{fg} / \mathrm{kg}$ and $10.2 \mathrm{fg} / \mathrm{kg}$, (Fig. 3B).

The shapes of the ${ }^{230} \mathrm{Th}_{\mathrm{xs}}$ and ${ }^{231} \mathrm{~Pa}_{\mathrm{xs}}$ deep profiles in the Eastern Basin are concave, with a linear increase from the surface down to $1000 \mathrm{~m}$ for ${ }^{231} \mathrm{~Pa}_{\mathrm{xs}}$ and to 1500 $\mathrm{m}$ for ${ }^{230} \mathrm{Th}_{\mathrm{xs}}$, with a maximum at $1500 \mathrm{~m}$ for ${ }^{231} \mathrm{~Pa}_{\mathrm{xs}}$ and $2500 \mathrm{~m}$ for ${ }^{230} \mathrm{Th}_{\mathrm{xs}}$ (Fig. $4 \mathrm{G}$ and H). Below these maxima, both the ${ }^{231} \mathrm{~Pa}_{\mathrm{xs}}$ and ${ }^{230} \mathrm{Th}_{\mathrm{xs}}$ concentrations decrease towards the seafloor. However, the relative decrease of ${ }^{230} \mathrm{Th}_{\mathrm{xs}}$ was smaller compared to the relative decrease of ${ }^{231} \mathrm{~Pa}_{\mathrm{xs}}$ (Fig. $4 \mathrm{G}$ and $\mathrm{H}$ ).

Similar ${ }^{231} \mathrm{~Pa}_{\mathrm{xs}}$ and ${ }^{230} \mathrm{Th}_{\mathrm{xs}}$ profile shapes were observed in the North and Central Algero-Balearic Basin, with concentration increasing linearly from the surface down to 500-1000 m for ${ }^{231} \mathrm{~Pa}_{\mathrm{xs}}$ (Fig. 4A, B, D and E). However, the linear concentration gradients extend to different depths across the basin. $\mathrm{The}^{230} \mathrm{Th}_{\mathrm{xs}}$ concentrations display a linear increase down to $500 \mathrm{~m}$ depth in the Northern Algero-Balearic Basin (NABB), down to $1000 \mathrm{~m}$ depth in the Central Algero-Balearic Basin (CABB) and the linear shape of the ${ }^{230} \mathrm{Th}_{\mathrm{xs}}$ profile in the Southern Algero-Balearic Basin (SABB) extends down to $1500 \mathrm{~m}$. Both the CABB and $\mathrm{SABB}{ }^{230} \mathrm{Th}_{\mathrm{xs}}$ depth profiles display a decrease in concentration towards the seafloor, below $1500 \mathrm{~m}$ depth (Fig. 4D). In the NABB at $2500 \mathrm{~m}$, the ${ }^{230} \mathrm{Th}_{\mathrm{xs}}$ concentration $(7.6 \pm 0.4 \mathrm{fg} / \mathrm{kg})$ was distinctly higher compared to the overlying water column, while the ${ }^{231} \mathrm{~Pa}_{\mathrm{xs}}$ concentration $(0.76 \pm 0.05 \mathrm{fg} / \mathrm{kg})$ was similar to overlying water (Fig. 4D and E).

Intermediate and deep waters $(<500 \mathrm{~m})$ from the Alboran Sea had significantly lower ${ }^{230} \mathrm{Th}_{\mathrm{xs}}$ concentrations $(2.7-3.6 \mathrm{fg} / \mathrm{kg})$ compared to ${ }^{230} \mathrm{Th}_{\mathrm{xs}}$ concentrations (2.7-5.6 $\mathrm{fg} / \mathrm{kg}$ ) in waters from the same depth in the Algero-Provencal Basin (NABB, CABB and SABB) (Fig. 4A and D).

Surface water (above $200 \mathrm{~m}$ depth) ${ }^{230} \mathrm{Th}_{\mathrm{xs}}$ concentrations at the Gibraltar strait (1.1-3.2 fg/kg) and in the Alboran Sea (2.4-2.7 fg/ $/ \mathrm{kg})$ were higher compared to surface ${ }^{230} \mathrm{Th}_{\mathrm{xs}}$ concentrations (1.3-1.7 fg/kg) in the Algero-Balearic Basin (CABB and SABB), 
while the ${ }^{231} \mathrm{~Pa}_{\mathrm{xs}}$ concentrations in the Alboran Sea $(0.14-0.54 \mathrm{fg} / \mathrm{kg})$ did not exceed the concentrations found in the Algero-Provencal (0.25-0.89 fg/kg) (Fig. 4A, B, D, E).

\section{${ }^{231} \mathrm{~Pa}$ and $\mathrm{Th}$-isotopes in suspended particles and the fractionation factor $\mathrm{F}_{\mathrm{Th} / \mathrm{Pa}}$}

The ${ }^{232}$ Th concentrations in the particulate fraction ranged between $3 \mathrm{pg} / \mathrm{kg}$ and 106 $\mathrm{pg} / \mathrm{kg}$ and generally decrease with depth. Higher ${ }^{232} \mathrm{Th}$ concentrations were found in the Western Basin (6.4-106 pg/kg) compared to the Eastern Basin (3-11 pg/kg). The maximum particulate ${ }^{232}$ Th concentration was found in the Alboran Sea at $100 \mathrm{~m}$ depth (Fig. 5, Tab. S3).

Particulate ${ }^{231} \mathrm{~Pa}_{\mathrm{xs}}$ concentrations ranged between $0.00036 \mathrm{fg} / \mathrm{kg}$ and 0.015 $\mathrm{fg} / \mathrm{kg}$. The particulate ${ }^{231} \mathrm{~Pa}_{\mathrm{xs}}$ concentrations increase with depth and higher concentrations were found in the Alboran Sea $\left({ }^{231} \mathrm{~Pa}_{\mathrm{xs}}\right.$ at $\left.100 \mathrm{~m}=0.005 \mathrm{fg} / \mathrm{kg}\right)$ and at CABB $\left({ }^{231} \mathrm{~Pa}_{\mathrm{xs}}\right.$ at $\left.1000 \mathrm{~m}=0.015 \mathrm{fg} / \mathrm{kg}\right)$ (Fig. 5, Tab. S3).

${ }^{230} \mathrm{Th}_{\mathrm{xs}}$ concentrations ranged between $0.003 \mathrm{fg} / \mathrm{kg}$ and $0.136 \mathrm{fg} / \mathrm{kg}$ and the concentrations displayed relatively constant concentrations throughout depth, with lower concentrations in surface waters compared to underlying deep water (Fig. 5, Tab. S3).

The particulate ${ }^{230} \mathrm{Th}_{\mathrm{xs}}{ }^{231} \mathrm{~Pa}_{\mathrm{xs}}$ ratios indicate a mid-depth maximum at $1000 \mathrm{~m}$ depth (Tab. S3). The $\mathrm{F}_{\mathrm{Th} / \mathrm{Pa}}$-values ranged from 1.4 to 9.0 and generally decrease with depth. No major differences in the calculated $\mathrm{F}_{\mathrm{Th} / \mathrm{Pa}}$ were observed between the Western and Eastern Basin (Fig. 6).

\section{Box-model results}

Comparing the net fluxes of ${ }^{231} \mathrm{~Pa}_{\mathrm{xs}}$ and ${ }^{230} \mathrm{Th}_{\mathrm{xs}}$ at the straits with the total in-situ production gives the balance of the transport and scavenging of ${ }^{231} \mathrm{~Pa}_{\mathrm{xs}}$ and ${ }^{230} \mathrm{Th}_{\mathrm{xs}}$ in the Mediterranean Sea. Any disequilibrium between the in-situ production of ${ }^{231} \mathrm{~Pa}_{\mathrm{xs}}$ and ${ }^{230} \mathrm{Th}_{\mathrm{xs}}$ and the net flux through the straits has to be balanced by removal of ${ }^{231} \mathrm{~Pa}_{\mathrm{xs}}$ and ${ }^{230} \mathrm{Th}_{\mathrm{xs}}$ from the water column by settling particles. An amount equivalent to $6 \%$ of the ${ }^{231} \mathrm{~Pa}_{\mathrm{xs}}$ produced in the Mediterranean Sea and an insignificant fraction $(0.1 \%)$ of the ${ }^{230} \mathrm{Th}_{\mathrm{xs}}$ produced in the Mediterranean Sea are exported to the Atlantic Ocean by the Mediterranean outflow water (MOW) at the Gibraltar Strait. Thus, the remaining $94 \%$ of the in-situ produced ${ }^{231} \mathrm{~Pa}_{\mathrm{xs}}$ and essentially all (99.9\%) the in-situ produced ${ }^{230} \mathrm{Th}_{\mathrm{xs}}$ are scavenged and deposited annually within the Mediterranean Sea.

Almost all of the in-situ produced ${ }^{230} \mathrm{Th}_{\mathrm{xs}}(99.9 \%)$ and a major fraction of the ${ }^{231} \mathrm{~Pa}_{\mathrm{xs}}(97 \%)$ in the Western Basin is also deposited within the Western Basin. Additionally, an amount equivalent to $5 \%$ of the ${ }^{230} \mathrm{Th}_{\mathrm{xs}}$ and $14 \%$ of the ${ }^{231} \mathrm{~Pa}_{\mathrm{xs}}$ produced 
in-situ in the Eastern Basin is exported to the Western Basin. This represents an extra input of $8 \%{ }^{230} \mathrm{Th}_{\mathrm{xs}}$ and $23 \%$ of the ${ }^{231} \mathrm{~Pa}_{\mathrm{xs}}$ produced in the Western Basin (Tab. 1). Thus, the Eastern Basin experiences a net loss of ${ }^{231} \mathrm{~Pa}_{\mathrm{xs}}$ and ${ }^{230} \mathrm{Th}_{\mathrm{xs}}$ by export to the Western Basin through the Strait of Sicily. The results demonstrate that $86 \%$ and $95 \%$ of the Eastern Basin in-situ produced ${ }^{231} \mathrm{~Pa}_{\mathrm{xs}}$ and ${ }^{230} \mathrm{Th}_{\mathrm{xs}}$ are trapped in Eastern Basin sediments, respectively (Tab 1).

\section{Discussion}

\section{Distribution of $\mathrm{Th}$ and $\mathrm{Pa}$ in the water column}

${ }^{230} \mathrm{Th}$ and ${ }^{232} \mathrm{Th}$ have previously been studied in the Mediterranean Sea (Roy-Barman et al., 2002). There is a good agreement between the ${ }^{230} \mathrm{Th}_{\mathrm{xs}}$ and ${ }^{232} \mathrm{Th}$ concentrations presented in this study and those reported from the DYFAMED site $\left({ }^{230} \mathrm{Th}_{\mathrm{xs}}=2.4-5.9\right.$ $\mathrm{fg} / \mathrm{kg},{ }^{232} \mathrm{Th}=171-377 \mathrm{pg} / \mathrm{kg}$ ). The DYFAMED site (Dynamics of Atmospheric Fluxes in the Mediterranean Sea) is located $\sim 110 \mathrm{~km}$ north off the NABB station (e.g. Roy-Barman et al., 2002). Conversely, the ${ }^{230} \mathrm{Th}_{\mathrm{xs}}$ concentrations from the Alboran Sea were lower compared to concentrations from previous studies (Roy-Barman et al., 2002). These samples were collected 17 years before MedSeA and the residence time of the water in the Western Basin is about $15 \mathrm{y}$ (see below), so differences in the water column distribution of ${ }^{230} \mathrm{Th}_{\mathrm{xs}}$ are not surprising.

In the Mediterranean Sea, the ${ }^{231} \mathrm{~Pa}_{\mathrm{xs}}$ and ${ }^{230} \mathrm{Th}_{\mathrm{xs}}$ depth profiles do not increase linearly with depth (Fig. 4) and thus deviate from the linear behavior predicted by the reversible scavenging model (Bacon and Anderson, 1982; Roy-Barman et al., 1996). This model does not consider lateral transport and thus the removal of Th and $\mathrm{Pa}$ from the water column is only a function of the vertical particle flux. The ${ }^{231} \mathrm{~Pa}_{\mathrm{xs}}$ and ${ }^{230} \mathrm{Th}_{\mathrm{xs}}$ concentrations in deep waters are lower compared to the concentrations predicted by the reversible scavenging model. This suggests that the ${ }^{231} \mathrm{~Pa}$ and ${ }^{230} \mathrm{Th}$ transport by the water movement is faster compared to particulate transport (e.g. Hayes et al., 2015a; Roy-Barman et al., 2009; Rutgers van der Loeff and Berger, 1993). This has also been demonstrated for the ${ }^{230} \mathrm{Th}_{\mathrm{xs}}$ distribution in the Western Mediterranean Sea (Roy-Barman et al., 2002).

As ${ }^{231} \mathrm{~Pa}$ has a longer scavenging residence time compared to ${ }^{230} \mathrm{Th}$ (about 200$400 \mathrm{y}$ for $\mathrm{Pa}$ and $20-40 \mathrm{y}$ for $\mathrm{Th}$ ), the non-linearity of the depth profiles is more pronounced for ${ }^{231} \mathrm{~Pa}$. This difference is noticeable in the depth profiles from the lonian and Levantine Sea (Fig. 4G, H). Furthermore, higher concentrations of ${ }^{231} \mathrm{~Pa}_{\mathrm{xs}}$ and ${ }^{230} \mathrm{Th}_{\mathrm{xs}}$ were observed in the waters of the Eastern Basin compared to the Western Basin (Fig. 
4D, $E, G, H)$. As the water residence time in the Eastern Basin $\left(T_{w}=61 \mathrm{y}\right)$ is longer compared to the Western Basin ( $\left.T_{w}=15 y\right)$, there is more time in the Eastern Basin for the concentrations to build up (Béthoux and Gentili, 1996).

The horizontal concentration gradient of ${ }^{231} \mathrm{~Pa}_{\mathrm{xs}}$ and ${ }^{230} \mathrm{Th}_{\mathrm{xs}}$ in intermediate and deep water between the Alboran Sea, Gibraltar and the Algero-Balearic Sea (Fig. 4A, B, $\mathrm{D}$, and E) may be explained by the removal of ${ }^{231} \mathrm{~Pa}_{\mathrm{xs}}$ and ${ }^{230} \mathrm{Th}_{\mathrm{xs}}$ on settling particles. This probably occurs somewhere in the Western Basin on the nearby continental slopes or during transport to, or in the Alboran Sea. The Alboran Sea is considered to be one of the most productive areas in the Mediterranean Sea (Masqué et al., 2003), which suggests that the abundance of suspended particulate matter is higher compared to other sub-basins in the area. Higher particle fluxes would induce higher scavenging rates of ${ }^{231} \mathrm{~Pa}$ and ${ }^{230} \mathrm{Th}$.

\section{The influence of deep water convection in the Western Mediterranean Basin}

In the North-western Mediterranean Sea, open sea convection and deep water shelf cascading can occur on an annual basis due to winter heat losses and evaporation (Houpert et al., 2016; Puig et al., 2013). Cascades of dense shelf waters can take place during several weeks and the associated strong currents can induce erosion and resuspension of surface sediments in the outer shelf/upper slope and generate nepheloid layers (Durrieu De Madron et al., 2013). During five consecutive winters (2009-2013), deep open ocean convection occurred, with a full depth water column mixing (Bethoux et al., 2002; Durrieu De Madron et al., 2013; Houpert et al., 2016; Marty and Chiavérini, 2010).

During the winter 2012-2013, the NABB station was within the convection area, which had its center at $42.06^{\circ} \mathrm{N} 4.64^{\circ} \mathrm{E}$ (Estournel et al., 2016). Winter cooling of surface water and deep convective mixing is expected to produce constant ${ }^{231} \mathrm{~Pa}_{\mathrm{xs}}$ and ${ }^{230} \mathrm{Th}_{\mathrm{xs}}$ concentration profiles, with high concentrations in the shallow water due to homogenization with deeper and more concentrated waters (Moran et al., 2002). The ${ }^{231} \mathrm{~Pa}_{\mathrm{xs}}$ and ${ }^{230} \mathrm{Th}_{\mathrm{xs}}$ depth profiles at the NABB station show higher surface and intermediate concentrations and thus seem to be more affected by the mixing of WMDW, LIW and MAW compared to the SABB and CABB profiles (Fig. 4D, E). A linear increase of the ${ }^{230} \mathrm{Th}_{\mathrm{xs}}$ concentrations was observed down to $500 \mathrm{~m}$ depth for the NABB profile, down to $1000 \mathrm{~m}$ depth for the CABB profile, while the linear shape of ${ }^{230} \mathrm{Th}_{\mathrm{xs}}$ profile in the SABB extended down to $1500 \mathrm{~m}$ (Fig. 4D). This indicates a gradual increase of the relative influence of reversible scavenging versus convection on the shapes of the ${ }^{230} \mathrm{Th}_{\mathrm{xs}}$ 
profiles along a north-south transect from NABB to SABB. Away from the deep water formation zone, the shapes of the ${ }^{231} \mathrm{~Pa}_{\mathrm{xs}}$ and ${ }^{230} \mathrm{Th}_{\mathrm{xs}}$ profiles become less influenced by convective mixing and the profile's shape is closer to linear equilibrium. Below the linear part of the profile, the depletion of both ${ }^{231} \mathrm{~Pa}_{\mathrm{xs}}$ and ${ }^{230} \mathrm{Th}_{\mathrm{xs}}$ with depth for the CABB and SABB profiles is consistent with ventilation through convective mixing (Fig. 7A) as suggested by the apparent oxygen utilization (AOU), which decreases from $500 \mathrm{~m}$ depth to the bottom indicating the arrival of newly ventilated water (Fig. 8). Nevertheless, although turbidity measurements (Fig. 7A) gave no hint of bottom nepheloid layers (BNL) at SABB and CABB during the MedSeA cruise, the effect of bottom scavenging cannot be excluded, because the spreading of dense cold water along the whole Algero-Balearic Basin leads up to a maximum of particulate matter at depths below $2000 \mathrm{~m}$ (Zúñiga et al., 2009).

In the NABB, turbidity measurements (Fig. 7A) showed a maximum between $2000 \mathrm{~m}$ and $2500 \mathrm{~m}$, accompanied by an enrichment of ${ }^{230} \mathrm{Th}_{\mathrm{xs}}$ and ${ }^{232} \mathrm{Th}$ (Fig. 4D, F). This is probably due to the presence of a BNL as a result of particle resuspension created by deep water cascading along the slope of the Gulf of Lions continental shelf. The concentration of ${ }^{231} \mathrm{~Pa}_{\mathrm{xs}}$ in seawater at the NABB station (2500 m depth) does not show the same deep water enrichment as for the ${ }^{230} \mathrm{Th}_{\mathrm{xs}}$ and ${ }^{232} \mathrm{Th}$. This suggests that the resuspended particulate matter in the nepheloid layer might be enriched in Th relative to $\mathrm{Pa}$. However, no particle samples were obtained at this station. The decoupling between ${ }^{231} \mathrm{~Pa}_{\mathrm{xs}},{ }^{230} \mathrm{Th}_{\mathrm{xs}}$ and ${ }^{232} \mathrm{Th}$ at $2500 \mathrm{~m}$ in NABB might reflect their sources. To confirm this, it would be necessary to obtain data for particle ${ }^{231} \mathrm{~Pa}_{\mathrm{xs}},{ }^{230} \mathrm{Th}_{\mathrm{xs}}$ and ${ }^{232} \mathrm{Th}$ within the BNL. Higher concentrations of ${ }^{232} \mathrm{Th}$ and ${ }^{230} \mathrm{Th}_{\mathrm{xs}}$ in seawater as well as depletions in the concentration of ${ }^{231} \mathrm{~Pa}_{\mathrm{xs}}$ relative to ${ }^{230} \mathrm{Th}_{\mathrm{xs}}$ associated with nepheloid layers have been reported from the North Atlantic and explained as an enrichment of lithogenic material (Hayes et al., 2015a).

As noted above, deep water formation in the area around the Gulf of Lions occasionally contributes to formation of BNLs in the North-western Mediterranean Basin. These nepheloid layers can persist for several years (Puig et al., 2013) and probably have a significant influence on the bottom water particle chemistry and biogeochemical cycling. Similarly, higher turbidity values were identified at $1000 \mathrm{~m}$ depth in the Alboran Sea which suggests the presence of a BNL (Fig. 7A). The occurrence of BNL in the Alboran Sea has been shown before (Masqué et al., 2003) and is suggested to have a significant influence on the transport and deposition of particulate material in deep waters of the Alboran Sea. 


\section{The influence of deep water ventilation in the Eastern Mediterranean Basin}

In the lonian and the Levantine Sea, a maximum ${ }^{231} \mathrm{~Pa}_{\mathrm{xs}}$ concentration $(1.04 \mathrm{fg} / \mathrm{kg})$ was observed between 1000 and $2500 \mathrm{~m}$ depth and a maximum ${ }^{230} \mathrm{Th}_{\mathrm{xs}}$ concentration (9.8 $\mathrm{fg} / \mathrm{kg}$ ) between 2000 and $2500 \mathrm{~m}$ depth (Fig. 4G, H). Below these depths, lower concentrations of both ${ }^{231} \mathrm{~Pa}_{\mathrm{xs}}$ and ${ }^{230} \mathrm{Th}_{\mathrm{xs}}$ were observed in bottom waters (Fig. 4G, H). This could be due to surface water transported at depth by convection. Alternatively, this could be caused by bottom scavenging. However, the low turbidity and decreasing AOU measured in the deep part of the Levantine and Ionian basins argue against deep scavenging by nepheloid layers (Fig. 7B and 8B).

In the 1990s, major convection events were observed in the Eastern Basin, usually referred to as the Eastern Mediterranean Transient, or EMT. During the EMT, the deep water formation area shifted from the Adriatic Sea to the Aegean Sea. Since then, the outflow of Aegean water still cause the uplift of EMDW and overlying water masses (MAW and LIW) (Roether et al., 1996; Schneider et al., 2014; Theocharis et al., 2002). The waters formed in the Aegean Sea have higher density compared to water that originates in the Adriatic Sea. Hence, the water can reach the deep layers of the Eastern Basin and thus will not penetrate the intermediate water depth range between 500 and $1000 \mathrm{~m}$ (Hassoun et al., 2015). The shape of the ${ }^{230} \mathrm{Th}_{\mathrm{xs}}$ profile is closer to the linear equilibrium profile compared to the ${ }^{231} \mathrm{~Pa}_{\mathrm{xs}}$ profile. This reflects a shorter scavenging residence time of ${ }^{230} \mathrm{Th}$ compared to ${ }^{231} \mathrm{~Pa}$ which allows a faster (although not yet complete) return of ${ }^{230} \mathrm{Th}$ to equilibrium since the EMT event.

\section{Particulate ${ }^{230} \mathrm{Th},{ }^{231} \mathrm{~Pa}$ and ${ }^{232} \mathrm{Th}$ in the Mediterranean Sea}

The particulate ${ }^{232} \mathrm{Th}$ concentrations are in the same range as previously reported for the Mediterranean Sea (Roy-Barman et al., 2002). In contrast to the ${ }^{232}$ Th concentrations, the particulate ${ }^{230} \mathrm{Th}_{\mathrm{xs}}$ values measured during MedSeA are lower than those previously reported for the Western Mediterranean Sea. For example, at the DYFAMED station (Roy-Barman et al., 2002), particulate ${ }^{230} \mathrm{Th}_{\mathrm{xs}}$ concentrations (> $0.2 \mu \mathrm{m}$ fraction) ranged from $0.7 \mathrm{fg} / \mathrm{kg}$ and $1.8 \mathrm{fg} / \mathrm{kg}$, which is more than one order of magnitude higher than the values obtained in the Algero Balearic Basin during MedSeA. The MedSeA particulate ${ }^{231} \mathrm{~Pa}_{\mathrm{xs}}$ and ${ }^{230} \mathrm{Th}_{\mathrm{xs}}$ concentrations are also lower compared to concentrations observed in the North-western Atlantic Ocean (e.g. particulate ${ }^{231} \mathrm{~Pa}_{\mathrm{xs}}=0.0014-0.07 \mathrm{fg} / \mathrm{kg}$, particulate ${ }^{230} \mathrm{Th}_{\mathrm{xs}}=0.13-3.1 \mathrm{fg} / \mathrm{kg}$, Hayes et al., 2015a). Low particulate Ba concentrations were also obtained during the MedSeA cruise (Roy-Barman et al., in prep.). 
These low concentrations could be caused by sampling artefacts or represent particular biogeochemical conditions. While the particulate ${ }^{230} \mathrm{Th}_{\mathrm{xs}}$ values measured in the MedSeA samples in the CABB and SABB are much lower than those previously reported at the DYFAMED station in the $>0.2 \mu \mathrm{m}$ fraction (Roy-Barman et al., 2002), it appears that the particulate ${ }^{232} \mathrm{Th}$ and ${ }^{230} \mathrm{Th}$ concentrations obtained during the MedSeA in the CABB and SABB are similar to the large particles ( $>60 \mu \mathrm{m}$ fraction) collected at DYFAMED (Roy-Barman et al., 2002). This suggests that during the MedSeA cruise, the large particles were recovered and the small fraction might have been under-sampled or partly lost. Therefore, in the following discussion, the MedSeA particulate concentrations will mainly be used to determine the particulate ${ }^{230} \mathrm{Th}_{\mathrm{xs}}{ }^{231} \mathrm{~Pa}_{\mathrm{xs}}$ ratio which is likely to be less sensitive to particle loss compared to the absolute concentrations. When absolute concentration data will be needed, e.g. for particle settling velocity determination, the particulate ${ }^{230} \mathrm{Th}_{\mathrm{xs}}$ data $(>0.2 \mu \mathrm{m})$ measured at the DYFAMED station (Roy-Barman et al., 2002) will be used, because we consider that it is more reliable and representative of ocean values.

Most of the ${ }^{232} \mathrm{Th}$ is introduced by lithogenic particles. The amount of ${ }^{232} \mathrm{Th}$ in rivers draining into Mediterranean Sea is not well characterized. However, assuming that particles in the rivers as well as in atmospheric dust, Saharan dust, have a composition close to that of average crust material $\left.{ }^{232} \mathrm{Th}=10-11 \mathrm{ppm}\right)$ an estimate of the amount of ${ }^{232}$ Th delivered to the Mediterranean through atmospheric dust and rivers can be made. Very different fluxes are reported for the suspended sediment load delivered by rivers to the Mediterranean Sea. According to Poulos and Collins (2002), the riverine sediment load is $379 \times 10^{6} \mathrm{t} / \mathrm{y}$ for the Western Basin and $279 \times 10^{6} \mathrm{t} / \mathrm{y}$ for the Eastern Basin. For the Western Basin, Martin et al. (2002) estimated a lower riverine particle flux of $57 \times 10^{6}$ t/y and considered that only $6 \times 10^{6} \mathrm{t} / \mathrm{y}(\sim 10 \%$ of the riverine load) reaches the open Western Basin because most of the river particulate load is stored in deltas and on the continental shelves. Dust fluxes reported for the Western Basin $\left(2-4 \times 10^{6} \mathrm{t} / \mathrm{y}\right)$ and for the Eastern Basin ( $8-16 \times 10^{6} \mathrm{t} / \mathrm{y}$ ) respectively (Jickells et al., 2002). So, if $\sim 90 \%$ of the river particulate load is stored in deltas and on the continental shelves and never reach the open Mediterranean Sea (Martin et al., 2002), the particulate material provided by rivers is at least as large as (and maybe significantly larger than) the Saharan dust flux.

The higher particulate ${ }^{232} \mathrm{Th}$ concentrations in the Western Basin (6.4 - 106 $\mathrm{pg} / \mathrm{kg}$ ) compared to the Eastern Basin (4.3-10.7 pg/ $/ \mathrm{kg}$ ) mainly illustrate higher loads of terrigenous material received from rivers and resuspension of sediments (Ludwig et al., 2009; Masqué et al., 2003). Essentially the entire Alboran Basin is covered with 
hemipelagic muds which contain up to $80 \%$ lithogenic material. The sedimentary conditions e.g. very fine grained sediments favors the occurrence of turbiditic flows that might supply "old material" rich in ${ }^{232}$ Th and other elements of lithogenic origin (Masqué et al., 2003). This could explain the high ${ }^{232}$ Th measured in particles (and seawater) samples at the strait of Gibraltar and in the Alboran Sea (Fig. 4C, Fig. 7, Tab. S3).

Particulate ${ }^{230} \mathrm{Th}_{\mathrm{xs}}$ concentrations showed a mid-depth maximum ( 1000 m), while the particulate ${ }^{231} \mathrm{~Pa}_{\mathrm{xs}}$ concentrations seem to decrease with depth, resulting in particulate ${ }^{230} \mathrm{Th}_{\mathrm{xs}} /{ }^{231} \mathrm{~Pa}_{\mathrm{xs}}$ ratios decreasing with depth (Tab. S3). This may be related to changes in the chemical composition of the particles which scavenge ${ }^{231} \mathrm{~Pa}$ and ${ }^{230} \mathrm{Th}$ as they settle through the water column (e.g. Moran et al., 2002).

In the open ocean, where particulate matter is dominated by calcium carbonate and/or clay, Th is scavenged preferentially to $\mathrm{Pa}$, which results in $\mathrm{F}_{\mathrm{Th} / \mathrm{Pa}} \approx 10-20$ (Chase et al., 2002; Luo and Ku, 1999; Moran et al., 2001, Hayes et al., 2015a). If ${ }^{231} \mathrm{~Pa}_{\mathrm{xs}}$ and ${ }^{230} \mathrm{Th}_{\mathrm{xs}}$ were equally removed onto particles, the ratio in the dissolved phase and the particulate phase would be identical, yielding a fractionation factor $\mathrm{F}_{\mathrm{Th} / \mathrm{Pa}} \sim 1$. In general, the $\mathrm{F}$ is low $\left(\mathrm{F}_{\mathrm{Th} / \mathrm{Pa}} \sim 1\right)$ if the particulate material is dominated by BSi (e.g. Chase et al., 2002; Venchiarutti et al., 2011) or when Mn-oxides are present (Anderson et al., 1983a). Laboratory experiments indicate that the $\mathrm{F}_{\mathrm{Th} / \mathrm{Pa}}$ is low $(\mathrm{F} \sim 1-2)$ for $\mathrm{Fe}_{2} \mathrm{O}_{3}, \mathrm{BSi}$ and $\mathrm{MnO}_{2}$ and generally higher for $\mathrm{Al}_{2} \mathrm{O}_{3}$ (F 9 - 12) (Geibert and Usbeck, 2004; Guo, 2002).

The $\mathrm{F}_{\mathrm{Th} / \mathrm{Pa}}$ values in the Mediterranean Sea are distinctly lower compared to values determined in the nearby subtropical Atlantic Ocean (Hayes et al., 2015a; Moran et al., 2002). The chemical composition of particles near margins may be different from that of the open ocean, so that adsorption no longer favors ${ }^{230} \mathrm{Th}$ over ${ }^{231} \mathrm{~Pa}$, resulting in lower $\mathrm{F}_{\mathrm{Th} / \mathrm{Pa}}$ values. As mentioned above, the two particulate phases known to have a significant affinity for $\mathrm{Pa}$ are biogenic silica and iron/manganese oxides. Due to the oligotrophic conditions prevailing in the Mediterranean Sea, the biogenic silica content of Mediterranean particles is low (Roy-Barman et al., 2009) and expected to yield a low scavenging rate of $\mathrm{Pa}$ (Hayes et al., 2015a). Fe- and Mn oxides are also efficient $\mathrm{Pa}$ (as well as Th) scavengers. Mn-oxides have been suggested to account for low $F_{T h / P a}$ values estimated for ocean margins before (Anderson et al., 1983). Mn-oxides have been proposed as a major Th carrier in the Mediterranean Sea (Roy-Barman et al., 2009). However, there is not a clear correlation between the $F_{T h / P a}$ and the particulate $M n$ content or $\mathrm{Mn}$ enrichment of the MedSeA particles (not shown). The particulate authigenic Mn content from the MedSeA particles is generally lower $(\mathrm{Mn}=0.3-9 \mathrm{ng} / \mathrm{kg})$ compared to the Atlantic Ocean (e.g $\mathrm{Mn}=\sim 5-50 \mathrm{ng} / \mathrm{kg}$, Twining et al., 2015), but as 
discussed previously, it may correspond to a sampling bias of the Mediterranean particles.

\section{Scavenging of ${ }^{231} \mathrm{~Pa}$ and ${ }^{230} \mathrm{Th}$ in the Mediterranean Sea}

Evaluating the influence of particle composition and enhanced particulate flux on the low $\mathrm{F}_{\mathrm{Th} / \mathrm{Pa}}$ at ocean margins is complicated due to the poorly constrained exchange of water between ocean margins and the open ocean (Nittrouer and Wright, 1994; Roy-Barman et al., 2009). However, the well constrained thermohaline circulation in the Mediterranean Sea can be used to establish budgets for ${ }^{231} \mathrm{~Pa}_{\mathrm{xs}}$ and ${ }^{230} \mathrm{Th}_{\mathrm{xs}}$ scavenging. Overall, all of the $(99.9 \%)$ in-situ produced ${ }^{230} \mathrm{Th}_{\mathrm{xs}}$ and $94 \%$ of the in-situ produced ${ }^{231} \mathrm{~Pa}_{\mathrm{xs}}$ are removed by settling particles within the Mediterranean Sea. Only a minor fraction, $0.1 \%$ of the ${ }^{230} \mathrm{Th}_{\mathrm{xs}}$ and $6 \%$ of the ${ }^{231} \mathrm{~Pa}_{\mathrm{xs}}$ of what is produced in-situ in the Mediterranean Sea is exported by Mediterranean deep water to the Atlantic Ocean. Higher amounts of exported ${ }^{231} \mathrm{~Pa}_{\mathrm{xs}}$, relative to exported ${ }^{230} \mathrm{Th}_{\mathrm{xs}}$ reflect lower affinity of ${ }^{231} \mathrm{~Pa}$ for marine particles. However, despite these differences, most ${ }^{231} \mathrm{~Pa}_{\mathrm{xs}}$ and ${ }^{230} \mathrm{Th}_{\mathrm{xs}}$ are removed into the Mediterranean Sea sediments. From these fractions, the mean ${ }^{230} \mathrm{Th}_{\mathrm{xs}}{ }^{231} \mathrm{~Pa}_{\mathrm{xs}}$ ratio in Mediterranean surface sediments was estimated:

$$
\left({ }^{230} \mathrm{Th}_{x S} /{ }^{231} \mathrm{~Pa} a_{x S}\right)_{\text {MedSed }}=\frac{P_{230 T h} \times 99.9 \%}{P_{231 P a} \times 94 \%}=27 \mathrm{fg} / \mathrm{fg}=11.6 \mathrm{dpm} / \mathrm{dpm}
$$

This is in gross agreement with the observed range of values of particulate data (Tab. S3), although the particulate data were not used to calculate this estimate. The efficient scavenging of ${ }^{231} \mathrm{~Pa}$ in the Mediterranean Sea produces a relatively low $\mathrm{F}_{\mathrm{Th} / \mathrm{Pa}}$ (Fig. 6). In terms of inter basin fluxes, $5 \%$ of the ${ }^{230} \mathrm{Th}_{\mathrm{xs}}$ and $14 \%$ of the ${ }^{231} \mathrm{~Pa}_{\mathrm{xs}}$ produced in-situ in the Eastern Basin is exported to the Western Basin. It represents an extra input of $8 \%$ of the ${ }^{230} \mathrm{Th}_{\mathrm{xs}}$ and $23 \%$ of the ${ }^{231} \mathrm{~Pa}_{\mathrm{xs}}$ produced in the Western Basin. This contributes to the relatively high ${ }^{231} \mathrm{~Pa}_{\mathrm{xs}}$ concentrations in the Western Basin despite the short water residence time.

The ${ }^{230} \mathrm{Th}_{\mathrm{xs}}$ budget indicates that there is no significant export to the Atlantic Ocean, so the removal must occur within the Mediterranean Sea in places of high sedimentation rates, probably by boundary scavenging along the continental slopes. The lack of ${ }^{230} \mathrm{Th}$ export to the Atlantic Ocean has significant implications for the determination of particle settling velocities derived from ${ }^{230} \mathrm{Th}$ distributions. Previously, low particle settling velocities $(250 \mathrm{~m} / \mathrm{y})$ were determined in the Western Mediterranean Sea using an advection-scavenging model (Roy-Barman et al., 2002). This low particle 
settling velocity arose from the concave shaped ${ }^{230} \mathrm{Th}$ profile suggesting that ${ }^{230} \mathrm{Th}$ removal in the deep water occurred by advection of newly formed deep water rather than by settling particles. This implied that ${ }^{230} \mathrm{Th}$ must be advected and scavenged elsewhere. Roy-Barman et al. (2002) implicitly assumed that it was exported to the Atlantic Ocean through the Gibraltar Strait. The ${ }^{230} \mathrm{Th}_{\mathrm{xs}}$ budget established in the present work demonstrates that this assumption is not valid as ${ }^{230} \mathrm{Th}_{\mathrm{xs}}$ is scavenged quantitatively in the Mediterranean basin. Therefore, we use a simple box model approach to determine the average particle setting speed in the Western Basin. The production of ${ }^{230} \mathrm{Th}_{\mathrm{xs}}$ in the Western Basin must be balanced by the settling of particulate ${ }^{230} \mathrm{Th}_{\mathrm{xs}}$ :

$$
S_{\text {small }}=\frac{P_{230 T h} \times h}{{ }^{230} T_{x S_{\text {_particulate }}}}
$$

where $S_{\text {small }}$ is the average settling velocity of small particles, $P_{230 T h}$ is the in-situ production rate of ${ }^{230} \mathrm{Th}_{\mathrm{xs}}, h$ is the water column depth and ${ }^{230} \mathrm{Th}_{\mathrm{xs} \text { _particulate }}$ is the concentration of ${ }^{230} \mathrm{Th}_{\mathrm{xs}}$ in the particulate fraction of the deep waters. Using equation 4, an average depth of $1500 \mathrm{~m}$ for the Western Basin and the DYFAMED data (particulate ${ }^{230} \mathrm{Th}_{\mathrm{xs}}=0.9-1.8 \mathrm{fg} / \mathrm{kg}$ at $1000 \mathrm{~m}$ and $2000 \mathrm{~m}$, obtained by subtracting the dissolved ${ }^{230} \mathrm{Th}_{\mathrm{xs}}$ from the total ${ }^{230} \mathrm{Th}_{\mathrm{xs}}$ in Roy-Barman et al. 2002), we estimate that $S_{\text {small }}$ is in the order of $500-1000 \mathrm{~m} / \mathrm{y}$. This value is rather high compared to the open ocean values but consistent with settling velocities expected at ocean margins (Roy-Barman, 2009).

Note that if the advection-scavenging model is applied to the present MedSeA particulate ${ }^{230} \mathrm{Th}_{\mathrm{xs}}$ data a settling velocity of about 60 times higher compared to RoyBarman et al. (2002) is obtained. This mainly reflects the low (and probably biased) particulate ${ }^{230} \mathrm{Th}$ contents measured during the MedSeA cruise, which is $\sim 60$ times less compared to values reported in Roy-Barman et al. (2002) 


\section{Conclusions}

The Mediterranean Sea ${ }^{232}$ Th distributions mainly reflect the input of lithogenic material from rivers and sediment resuspension. When ${ }^{231} \mathrm{~Pa}_{\mathrm{xs}}$ and ${ }^{230} \mathrm{Th}_{\mathrm{xs}}$ are only transported by reversible scavenging on settling particles, linear depth profiles are expected. In the Mediterranean Sea, the non-linear shape of the ${ }^{231} \mathrm{~Pa}_{\mathrm{xs}}$ and ${ }^{230} \mathrm{Th}_{\mathrm{xs}}$ depth profiles indicates that the profiles are overprinted by deep water circulation. Total ${ }^{231} \mathrm{~Pa}_{\mathrm{xs}}$ and ${ }^{230} \mathrm{Th}_{\mathrm{xs}}$ distributions in seawater from the Western Basin of the Mediterranean Sea show a clear impact of convective mixing with relatively high concentrations in the shallow water, followed by lower concentrations in the deep water due to recent homogenization by convection. In contrast to the homogeneity of the ${ }^{231} \mathrm{~Pa}_{\mathrm{xs}}$ and ${ }^{230} \mathrm{Th}_{\mathrm{xs}}$ profile shapes in the Western Basin, the distribution of ${ }^{231} \mathrm{~Pa}_{\mathrm{xs}}$ and ${ }^{230} \mathrm{Th}_{\mathrm{xs}}$ in the Eastern Basin of the Mediterranean Sea indicates the presence of younger but denser Aegean deep water, while elevated concentrations indicate the presence of older uplifted Adriatic water. Essentially all the in-situ produced ${ }^{230} \mathrm{Th}_{\mathrm{xs}}(99.9 \%)$ is scavenged and deposited within the Mediterranean Sea. It leads to a reevaluation the mean particle settling speed estimated with the ${ }^{230} \mathrm{Th}_{\mathrm{xs}}$ method that must allow boundary scavenging and not only scavenging and convection like in Roy-Barman et al. (2002). Despite lower affinity of ${ }^{231} \mathrm{~Pa}$ for marine particles (relative to ${ }^{230} \mathrm{Th}$ ), most of the Mediterranean in-situ produced ${ }^{231} \mathrm{~Pa}(94 \%)$ is also deposited in Mediterranean sediments. The efficient scavenging of ${ }^{231} \mathrm{~Pa}$ in the Mediterranean Sea produces a relatively low $\mathrm{F}_{\mathrm{Th} / \mathrm{Pa}}$. It would be interesting to analyze ${ }^{231} \mathrm{~Pa}$ in sediment traps moored in the Mediterranean Sea to be able to clearly identify the cause for the efficient scavenging of ${ }^{231} \mathrm{~Pa}$ and thus gain insight on scavenging at ocean margins.

\section{Acknowledgements}

This work was conducted in the framework of the GEOTRACES program and was supported by the Swedish Research Council (VR 349-202-6287). This work was funded by the European Union 7th Framework Program (MedSeA grant no. 265103), the Ministerio de Economía y Competitividad of Spain (MDM2015-0552) and the Generalitat de Catalunya (MERS 2014 SGR- 1356). The authors are pleased to thank the captains and the crew of the Spanish research vessel R/V Angeles Alvarino. Nuria Casacuberta, Maxi Castrillejo and Montserrat Roca Marti are thanked for the sampling of water and particles. Louise Bordier and Karin Wallner are acknowledged for their critical roles in the laboratory work. Patrick Laceby is acknowledged for helpful comments on early drafts of 
the manuscript. The constructive comments of 2 anonymous reviewers greatly improved the present article. This is an LSCE contribution. 


\section{References}

Anderson, R.F., Bacon, M.P., Brewer, P.G., 1983. Removal of 230Th and 231Pa from the Open Ocean. Earth Planet. Sci. Lett. 62, 7-23. doi:10.1016/0012-821X(83)90067-5

Anderson, R.F., Bacon, M.P., Brewer, P.G., 1983. Removal of 230Th and 231Pa at Ocean Margins. Earth Planet. Sci. Lett. 66, 73-90. doi:10.1016/0012-821X(83)90127-9

Anderson, R.F., Fleisher, M.Q., Robinson, L.F., Edwards, R.L., Hoff, J. a., Moran, S.B., Loeff, M.R. Van Der, Thomas, A.L., Roy-Barman, M., Francois, R., 2012. GEOTRACES intercalibration of 230Th, 232Th, 231Pa, and prospects for 10Be. Limnol. Oceanogr. Methods 10, 179-213. doi:10.4319/lom.2012.10.179

Bacon, M.P., 2005. Chapter 5 Reactive radionuclides as tracers of oceanic particle flux. Radioact. Environ. 6, 139-165. doi:10.1016/S1569-4860(05)80006-3

Bacon, M.P., Anderson, R.F., 1982. Distribution of Thorium isotopes between dissolved and particulate forms in the deep sea. J. Geophys. Res. 87, 2045-2056. doi:10.1029/JC087iC03p02045

Beranger, K., Mortier, L., Gasparini, G., Gervasio, L., Astraldi, M., Crépon, M., 2004. The dynamics of the Sicily Strait : a comprehensive study from observations and models 51 , 411-440. doi:10.1016/j.dsr2.2003.08.004

Béthoux, J.-P., Gentili, B., 1999. Functioning of the Mediterranean Sea: past and present changes related to freshwater imput and climate changes. J. Mar. Syst. 20, 33-47. doi:10.1016/s0924-7963(98)00069-4

Bethoux, J.P., Durieu de Madron, X., Nyffeler, F., Tailliez, D., 2002. Deep water in the western Mediterranean: Peculiar 1999 and 2000 characteristics, shelf formation hypothesis, variability since 1970 and geochemical inferences. J. Mar. Syst. 33-34, 117-131. doi:10.1016/S0924-7963(02)00055-6

Boldrin, A., Miserocchi, S., Rabitti, S., Turchetto, M.M., Balboni, V., Socal, G., 2002. Particulate matter in the southern Adriatic and Ionian Sea : characterisation and downward fluxes. J. Mar. Syst. 33-34, 389-410.

Buesseler, K.O., Antia, A.N., Chen, M., Fowler, S.W., Gardner, W.D., Gustafsson, O., Harada, K., Michaels, A.F., Rutgers van der Loeff, M., Sarin, M., Steinberg, D.K., Trull, T., 2007. An assessment of the use of sediment traps for estimating upper ocean particle fluxes. J. Mar. Res. 65, 345-416. doi:10.1357/002224007781567621

Castellari, S., Pinardi, N., Leaman, K., 2000. Simulation of water mass formation processes in the Mediterranean Sea: Influence of the time frequency of the atmospheric forcing. J. Geophys. Res. 105. 24157-24181. doi: 10.1029/2000JC900055

Chase, Z., Anderson, R.F., Fleisher, M.Q., Kubik, P.W., 2002. The influence of particle composition and particle flux on scavenging of $\mathrm{Th}, \mathrm{Pa}$ and $\mathrm{Be}$ in the ocean. Earth Planet. Sci. Lett. 204, 215-229. doi:10.1016/S0012-821X(02)00984-6

Cheng, H., Edwards, R.L., Murrell, M.T., Benjamin, T.M., 1998. Uranium-thoriumprotactinium dating systematics. Geochim. Cosmochim. Acta 62, 3437-3452. doi:http://dx.doi.org/10.1016/S0016-7037(98)00255-5

Condon, D.J., McLean, N., Noble, S.R., Bowring, S.A., 2010. Isotopic composition $(238 \mathrm{U} / 235 \mathrm{U})$ of some commonly used uranium reference materials. Geochim. Cosmochim. Acta 74, 7127-7143. doi:10.1016/j.gca.2010.09.019 
Deng, F., Thomas, A.L., Rijkenberg, M.J.A., Henderson, G.M., 2014. Controls on seawater $231 \mathrm{~Pa}, 230 \mathrm{Th}$ and 232Th concentrations along the flow paths of deep waters in the Southwest Atlantic. Earth Planet. Sci. Lett. 390, 93-102. doi:10.1016/j.epsl.2013.12.038

Durrieu De Madron, X., Houpert, L., Puig, P., Sanchez-Vidal, A., Testor, P., Bosse, A., Estournel, C., Somot, S., Bourrin, F., Bouin, M.N., Beauverger, M., Beguery, L., Calafat, A., Canals, M., Cassou, C., Coppola, L., Dausse, D., D'Ortenzio, F., Font, J., Heussner, S., Kunesch, S., Lefevre, D., Le Goff, H., Martín, J., Mortier, L., Palanques, A., Raimbault, P., 2013. Interaction of dense shelf water cascading and open-sea convection in the northwestern Mediterranean during winter 2012. Geophys. Res. Lett. 40, 1379-1385. doi:10.1002/grl.50331

El-Geziry, T.M., Bryden, I.G., 2010. The circulation pattern in the mediterranean sea: Issues for modeller consideration. J. Oper. Oceanogr. 3, 39-46. doi:10.1080/1755876X.2010.11020116

El Rahman Hassoun, A., Guglielmi, V., Gemayel, E., Goyet, C., Abboud-Abi Saab, M., Giani, M., Ziveri, P., Ingrosso, G., Touratier, F., 2015. Is the Mediterranean Sea Circulation in a Steady State. J. Water Resour. Ocean Sci. 4, 6-17. doi:10.11648/j.wros.20150401.12

Estournel, C., Testor, P., Damien, P., D’Ortenzio, F., Marsaleix, P., Conan, P., Belamari, S., 2016. High resolution modeling of dense water formation in the north western Mediterranean during winter 2012-2013: Processes and Budget. J. Geophys. Res. Ocean. 121, 5367-5392.

Geibert, W., Usbeck, R., 2004. Adsorption of thorium and protactinium onto different particle types: Experimental findings. Geochim. Cosmochim. Acta 68, 1489-1501. doi:10.1016/j.gca.2003.10.011

Guo, L., 2002. Control of $\mathrm{Pa} / \mathrm{Th}$ ratio by particulate chemical composition in the ocean. Geophys. Res. Lett. 29, 20-23. doi:10.1029/2002GL015666

Hayes, C.T., Anderson, R.F., Fleisher, M.Q., Huang, K.F., Robinson, L.F., Lu, Y., Cheng, H., Edwards, R.L., Moran, S.B., 2015a. ${ }^{230}$ Th and ${ }^{231} \mathrm{~Pa}$ on GEOTRACES GA03, the U.S. GEOTRACES North Atlantic transect, and implications for modern and paleoceanographic chemical fluxes. Deep. Res. Part II Top. Stud. Oceanogr. 116, 2941. doi:10.1016/j.dsr2.2014.07.007

Hayes, C.T., Anderson, R.F., Fleisher, M.Q., Vivancos, S.M., Lam, P.J., Ohnemus, D.C., Huang, K.F., Robinson, L.F., Lu, Y., Cheng, H., Edwards, R.L., Moran, S.B., 2015b. Intensity of Th and $\mathrm{Pa}$ scavenging partitioned by particle chemistry in the North Atlantic Ocean. Mar. Chem. 170, 49-60. doi:10.1016/j.marchem.2015.01.006

Houpert, L., Durrieu de Madron, X., Testor, P., Bosse, A., D’Ortenzio, F., Bouin, M.N., Dausse, D., Le Goff, H., Kunesch, S., Labaste, M., Coppola, L., Mortier, L., Raimbault, P., 2016. Observations of Open-Ocean deep convection in the Northwestern Mediterranean Sea: Seasonal and inter-annual variability of mixing and deep water masses for the 2007-2013 period. J. Geophys. Res. Ocean. 121, 8139-8171.

Jeandel, C., Rutgers van der Loeff, M., Lam, P.J., Roy-Barman, M., Sherrell, R.M., Kretschmer, S., German, C., Dehairs, F., 2015. What did we learn about ocean particle dynamics in the GEOSECS-JGOFS era? Prog. Oceanogr. 133, 6-16. doi:10.1016/j.pocean.2014.12.018

Jeandel, C., Venchiarutti, C., Bourquin, M., Pradoux, C., Lacan, F., van Beek, P., Riotte, J., 2011. Single column sequential extraction of $\mathrm{Ra}, \mathrm{Nd}$, Th, $\mathrm{Pa}$ and $\mathrm{U}$ from a natural sample. Geostand. Geoanalytical Res. 35, 449-459. doi:10.1111/j.1751- 
Jickells T. D., An, Z. S., Andersen, K. K., Baker A. R., Bergametti G., Brooks N., Cao J. J., Boyd P. W., Duce R. A., Hunter K. A. Kawahata H., Kubilay N., laRoche J., Liss P. S., Mahowald N., Prospero J. M., Ridgwell A. J., Tegen I., Torres R., 2005: Global iron connections between desert dust, ocean biogeochemistry, and climate, Science, 308, 67-71

Lal, D., 1977. The Oceanic Microcosm of Particles. Science (80-. ). 198, 997-1009. doi:10.2307/1745337

Lippold, J., Luo, Y., Francois, R., Allen, S.E., Gherardi, J., Pichat, S., Hickey, B., Schulz, H., 2012. Strength and geometry of the glacial Atlantic Meridional Overturning Circulation. Nat. Geosci. 5, 813-816. doi:10.1038/ngeo1608

Ludwig, W., Dumont, E., Meybeck, M., Heussner, S., 2009. Progress in Oceanography River discharges of water and nutrients to the Mediterranean and Black Sea: Major drivers for ecosystem changes during past and future decades ? Prog. Oceanogr. 80, 199-217. doi:10.1016/j.pocean.2009.02.001

Luo, S., Ku, T.L., 1999. Oceanic 231Pa/230Th ratio influenced by particle composition and remineralization. Earth Planet. Sci. Lett. 167, 183-195. doi:10.1016/S0012$821 \times(99) 00035-7$

Martin, J., George, A., Knauer, E., Karl, D., Broenkow, W., 1987. V E R T E X: c a r b o n cycling in the northeast Pacific. Deep-Sea Research. 34, 267-285.

Martin, J. M., Elbaz-Poulichet, F., Guieu, C., Loÿe-Pilot, M. D., \& Han, G., 1989: River versus atmospheric input of material to the Mediterranean Sea: an overview. Marine Chemistry, 28(1-3), 159-182.

Marty, J.C., Chiavérini, J., 2010. Hydrological changes in the Ligurian Sea (NW Mediterranean, DYFAMED site) during 1995-2007 and biogeochemical consequences. Biogeosciences 7, 2117-2128. doi:10.5194/bg-7-2117-2010

Masqué, P., Fabres, J., Canals, M., Sanchez-Cabeza, J.A., Sanchez-Vidal, A., Cacho, I., Calafat, A.M., Bruach, J.M., 2003. Accumulation rates of major constituents of hemipelagic sediments in the deep Alboran Sea: A centennial perspective of sedimentary dynamics. Mar. Geol. 193, 207-233. doi:10.1016/S0025-3227(02)00593-5

Millot, C., 1999. Circulation in the Western Mediterranean Sea. J. Mar. Syst. 20, 423-442. doi:10.1016/S0924-7963(98)00078-5

Miquel, J.C., Fowler, S.W., La Rosa, J., Buat-Menard, P., 1994. Dynamics of the downward flux of particles and carbon in the open northwestern Mediterranean Sea. Deep. Res. Part I 41, 243-261. doi:10.1016/0967-0637(94)90002-7

Moran, S.B., Shen, C.-C., Weinstein, S.E., Hettinger, L.H., Hoff, J.H., E dmonds, H.N., Edwards, R.L., 2001. Constraints on deep water age and particle flux in the Equatorial and South Atlantic Ocean based on seawater231Pa and230Th data. Geophys. Res. Lett. 28, 3437-3440.

Moran, S.B., Shen, C.C., Edmonds, H.N., Weinstein, S.E., Smith, J.N., Edwards, R.L., 2002. Dissolved and particulate 231 Pa and 230Th in the Atlantic Ocean: Constraints on intermediate/deep water age, boundary scavenging, and 231 Pa/230Th fractionation. Earth Planet. Sci. Lett. 203, 999-1014. doi:10.1016/S0012-821X(02)00928-7 
Nittrouer, C.A., Wright, L.D., 1994. Transport of particles across continental shelves. Rev. Geophys. 32, 85-113. doi:10.1029/93RG02603

Owens, S.A., Buesseler, K.O., Sims, K.W.W., 2011. Re-evaluating the 238U-salinity relationship in seawater: Implications for the 238U-234Th disequilibrium method. Mar. Chem. 127, 31-39. doi:10.1016/j.marchem.2011.07.005

Poulos S. E., Collins M. B., 2002: Fluviatile sediment fluxes to the Mediterranean Sea: a quantitative approach and influence of dams. Geological Society Special Publication [Internet]. 191:227-245

Puig, P., Madron, X.D. de, Salat, J., Schroeder, K., Martín, J., Karageorgis, A.P., Palanques, A., Roullier, F., Lopez-Jurado, J.L., Emelianov, M., Moutin, T., Houpert, L., 2013. Thick bottom nepheloid layers in the western Mediterranean generated by deep dense shelf water cascading. Prog. Oceanogr. 111, 1-23. doi:10.1016/j.pocean.2012.10.003

Pujo-Pay, M., Conan, P., Oriol, L., Cornet-Barthaux, V., Falco, C., Ghiglione, J.F., Goyet, C., Moutin, T., Prieur, L., 2011. Integrated survey of elemental stoichiometry (C, N, P) from the western to eastern Mediterranean Sea. Biogeosciences 8, 883-899. doi:10.5194/bg8-883-2011

Robinson, A.R., Hecht, A., Michelato, A., Roether, W., Theocharis, A., Unliiata, U., Pinardi, N., Bergamasco, A.A.A., Bishop, J., Brenner, S., Christianidis, S., Gacic, M.J., Georgopoulos, D., Golnaraghi, M., Hausmann, M., Junghaus, H., Lascaratos, A., Latif, M.A., Leslie, W.G., Lozano, C.J., O, T., Idzsoy, E., Papageorgiou, E., Paschini, E., Rozentroub, Z., Sansone, E., Schlitzer, R., Spezie, G., Tziperman, E., Zodiatis, G., Gerges, L.A.M., Osman, M., Group, P., 1992. General circulation of the Eastern Mediterranean. Earth-Science Rev. 32, 285-309. doi:http://dx.doi.org/10.1016/00128252(92)90002-B

Roether, W., Manca, B.B., Klein, B., Bregant, D., Georgopoulos, D., Beitzel, V., Kovacevic, V., Luchetta, A., 1996. Recent Changes in Eastern Mediterranean Deep Waters. Science. 271, 333-335.

Roy-Barman, M., 2009. Modelling the effect of boundary scavenging on Thorium and Protactinium profiles in the ocean. Biogeosciences. 6, 3091-3107. doi: 10.5194/bg-63091-2009

Roy-Barman, M., Chen, J.H., Wasserburg, G.J., 1996. The sources and the fates of thorium. Earth Planet. Sci. Lett. 139, 351-363.

Roy-Barman, M., Coppola, L., Souhaut, M., 2002. Thorium isotopes in the western Mediterranean Sea: An insight into the marine particle dynamics. Earth Planet. Sci. Lett. 196, 161-174. doi:10.1016/S0012-821X(01)00606-9

Roy-Barman, M., Lemaître, C., Ayrault, S., Jeandel, C., Souhaut, M., Miquel, J.C., 2009. The influence of particle composition on Thorium scavenging in the Mediterranean Sea. Earth Planet. Sci. Lett. 286, 526-534. doi:10.1016/j.epsl.2009.07.018

Rutgers van der Loeff, M.M., Berger, G.W., 1993. Scavenging of 230Th and 231Pa near the antarctic polar front in the South Atlantic. Deep. Res. Part I 40, 339-357. doi:10.1016/0967-0637(93)90007-P

Schneider, A., Tanhua, T., Roether, W., Steinfeldt, R., 2014. Changes in ventilation of the mediterranean Sea during the past 25 year. Ocean Sci. 10, 1-16. doi:10.5194/os-10-12014 
Siddall, M., Henderson, G.M., Edwards, N.R., Frank, M., Müller, S.A., Stocker, T.F., Joos, F., 2005. 231 Pa/230Th fractionation by ocean transport, biogenic particle flux and particle type. Earth Planet. Sci. Lett. 237, 135-155. doi:10.1016/j.epsl.2005.05.031

Theocharis, A., Klein, B., Nittis, K., Roether, W., 2002. Evolution and status of the Eastern Mediterranean Transient (1997-1999). J. Mar. Syst. 33-34, 91-116. doi:10.1016/S09247963(02)00054-4

Tsimplis, M.N., 2000. Vertical structure of tidal currents over the Camarinal Sill at the Strait of Gibraltar. J. Geophys. Res. 105, 709-719.

Twining, B.S., Rauschenberg, S., Morton, P.L., Vogt, S., 2015. Metal contents of phytoplankton and labile particulate material in the North Atlantic Ocean. Prog. Oceanogr. 137, 261-283. doi:10.1016/j.pocean.2015.07.001

Venchiarutti, C., van der Loeff, M.R., Stimac, I., 2011. Scavenging of 231Pa and thorium isotopes based on dissolved and size-fractionated particulate distributions at Drake Passage (ANTXXIV-3). Deep. Res. Part II Top. Stud. Oceanogr. 58, 2767-2784. doi:10.1016/j.dsr2.2010.10.040

Walter, H.J., Rutgers van der Loeff, M.M., Hoeltzen, H., 1997. Enhanced scavenging of 231Pa relative to 230Th in the South Atlantic south of the Polar Front: Implications for the use of the $231 \mathrm{~Pa} / 230 \mathrm{Th}$ ratio as a paleoproductivity proxy. Earth Planet. Sci. Lett. 149, 85-100. doi:10.1016/S0012-821X(97)00068-X

Yu, E.-F., Francois, R., Bacon, M.P., 1996. Similar rates of modern and last-glacial ocean thermohaline circulation inferred from radiochemical data. Nature. doi:10.1038/379689a0

Zúñiga, D., Flexas, M.M., Sanchez-Vidal, A., Coenjaerts, J., Calafat, A., Jordà, G., GarcíaOrellana, J., Puigdefàbregas, J., Canals, M., Espino, M., Sardà, F., Company, J.B., 2009. Particle fluxes dynamics in Blanes submarine canyon (Northwestern Mediterranean). Prog. Oceanogr. 82, 239-251. doi:10.1016/j.pocean.2009.07.002

\section{Figure and table captions:}

Figure 1. Map of Pa-Th sampling sites during the 2013 MedSeA-GA04-S cruise. Black points represent sampling sites $(n=10)$ for seawater and triangles represent sampling sites $(n=6)$ for suspended particulate matter. Arrows show the exchange of water between the Western Basin and the Atlantic Ocean (Strait of Gibraltar) and between the Western and Eastern Basin (Strait of Sicily). SABB: Southern Algero-Balearic Basin, CABB: Central Algero-Balearic Basin and NABB: Northern Algero-Balearic Basin.

Figure 2. Section plot of salinity for the Mediterranean transect with the Atlantic Water (AW), the Modified Atlantic Water (MAW), the Western Mediterranean Deep Water (WMDW), the Levantine Intermediate Water (LIW) and Eastern Mediterranean Deep Water (EMDW) of Adriatic origin $\left(E M D W_{A d r}\right)$ and Aegean origin $\left(E M_{D W}\right)$ marked in black.

Figure 3. Section plots for the Mediterranean Sea transect showing concentrations of $(A)$ ${ }^{231} \mathrm{~Pa}_{\mathrm{xs}}$, (B) ${ }^{230} \mathrm{Th}_{\mathrm{xs}}$, and (C) ${ }^{232} \mathrm{Th}$ measured in unfiltered seawater. The ${ }^{231} \mathrm{~Pa}_{\mathrm{xs}}$ and ${ }^{230} \mathrm{Th}_{\mathrm{xs}}$ concentrations are given in $\mathrm{fg} / \mathrm{kg}$ and ${ }^{232} \mathrm{Th}$ concentrations are given in $\mathrm{pg} / \mathrm{kg}$. Data points are 
shown as black dots. Note the large section distances between the stations in the Alboran Sea and SABB, thus the interpolations are not well determined.

Figure 4. Depth profiles of total ${ }^{231} \mathrm{~Pa}_{\mathrm{xs}},{ }^{230} \mathrm{Th}_{\mathrm{xs}}$ and ${ }^{232} \mathrm{Th}$ in the Mediterranean Sea.

Figure 5. Depth profiles of particulate ${ }^{231} \mathrm{~Pa}_{\mathrm{xs}},{ }^{230} \mathrm{Th}_{\mathrm{xs}}$ and ${ }^{232} \mathrm{Th}$ in the Mediterranean Sea. The concentration of particulate ${ }^{231} \mathrm{~Pa}_{\mathrm{xs}}$ and ${ }^{230} \mathrm{Th}_{\mathrm{xs}}$ at $\mathrm{CABB}, 1000 \mathrm{~m}$ depth was not included due to the large errors (Tab. S3).

Figure 6. $\mathrm{F}_{\mathrm{Th} / \mathrm{Pa}}$ calculated between seawater and suspended particles in the water column

Figure 7. Turbidity (Nephelometric Turbidity Units, NTU) profiles for (A) the Western Basin and $(B)$ the Eastern Basin. No specific calibration was done to determine the absolute particle concentrations, so only relative variations are considered.

Figure 8. Apparent oxygen utilization (AOU) profiles for $(A)$ the Western Basin and $(B)$ the Eastern Basin.

Table 1. Concentrations and fluxes of ${ }^{231} \mathrm{~Pa}_{\mathrm{xs}}$ and ${ }^{230} \mathrm{Th}_{\mathrm{xs}}$. Water fluxes used and box model calculations were derived from Bethoux and Gentili (1996). Net fluxes and in-situ production rates of ${ }^{231} \mathrm{~Pa}_{\mathrm{xs}}$ and ${ }^{230} \mathrm{Th}_{\mathrm{xs}}$ for the Western and Eastern Basin were calculated using the equations in table $\mathrm{S} 1$.

\section{Supplementary information:}

Table S1. Parameters and equations used for box model calculations.

Table S2. Seawater concentrations of total ${ }^{231} \mathrm{~Pa},{ }^{230} \mathrm{Th},{ }^{232} \mathrm{Th}$, in-situ produced ${ }^{231} \mathrm{~Pa}_{\mathrm{xs}}{ }^{230} \mathrm{Th}_{\mathrm{xs}}$ and ${ }^{230} \mathrm{Th}_{\mathrm{xs}} /{ }^{231} \mathrm{~Pa}_{\mathrm{xs}}$ activity ratios.

Table S2. Continued

Table s3. Concentrations of ${ }^{231} \mathrm{~Pa}_{\mathrm{xs}}{ }^{230} \mathrm{Th}_{\mathrm{xs}},{ }^{232} \mathrm{Th}$ and ${ }^{230} \mathrm{Th}_{\mathrm{xs}}{ }^{231} \mathrm{~Pa}_{\mathrm{xs}}$ activity ratios for suspended particles. 


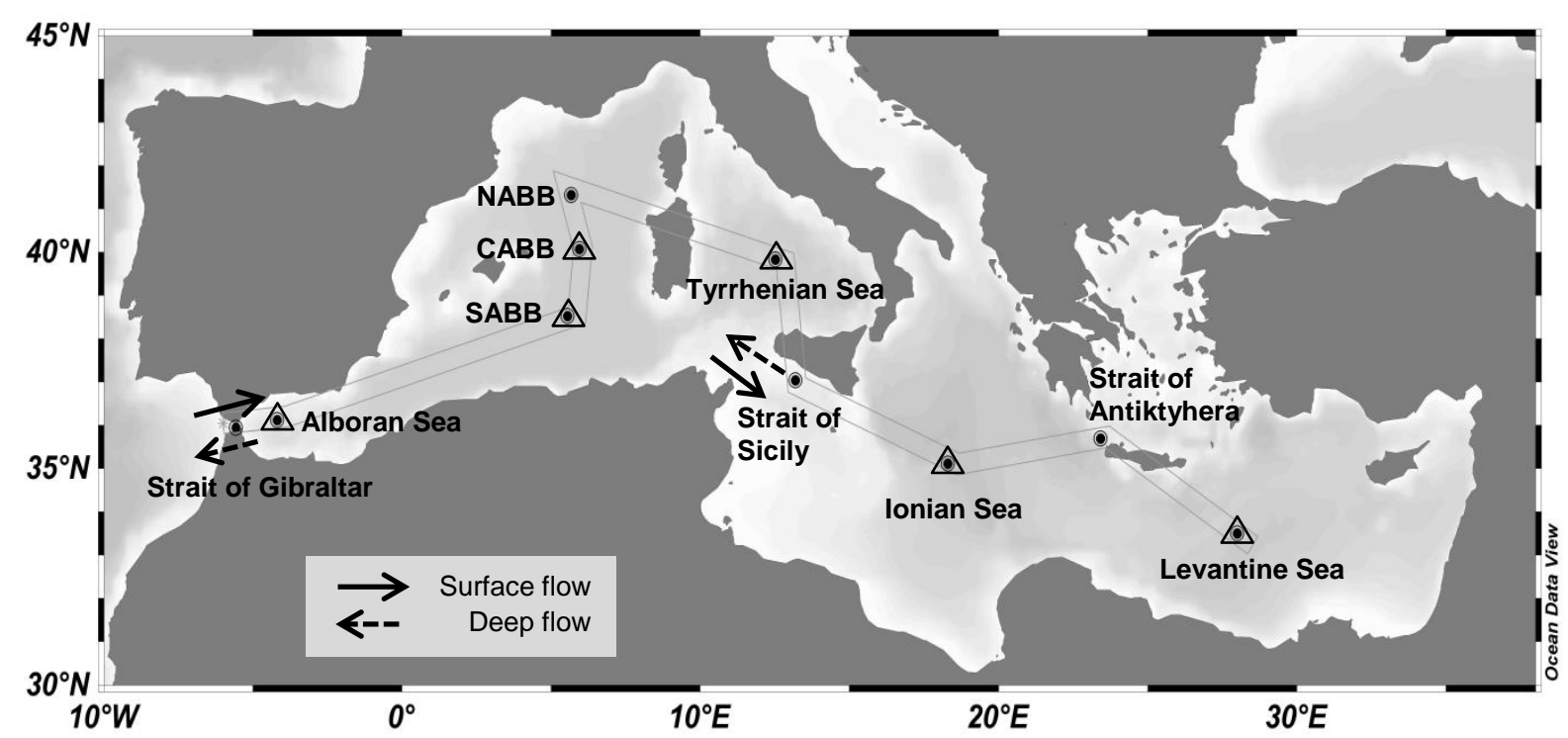

Fig. 1

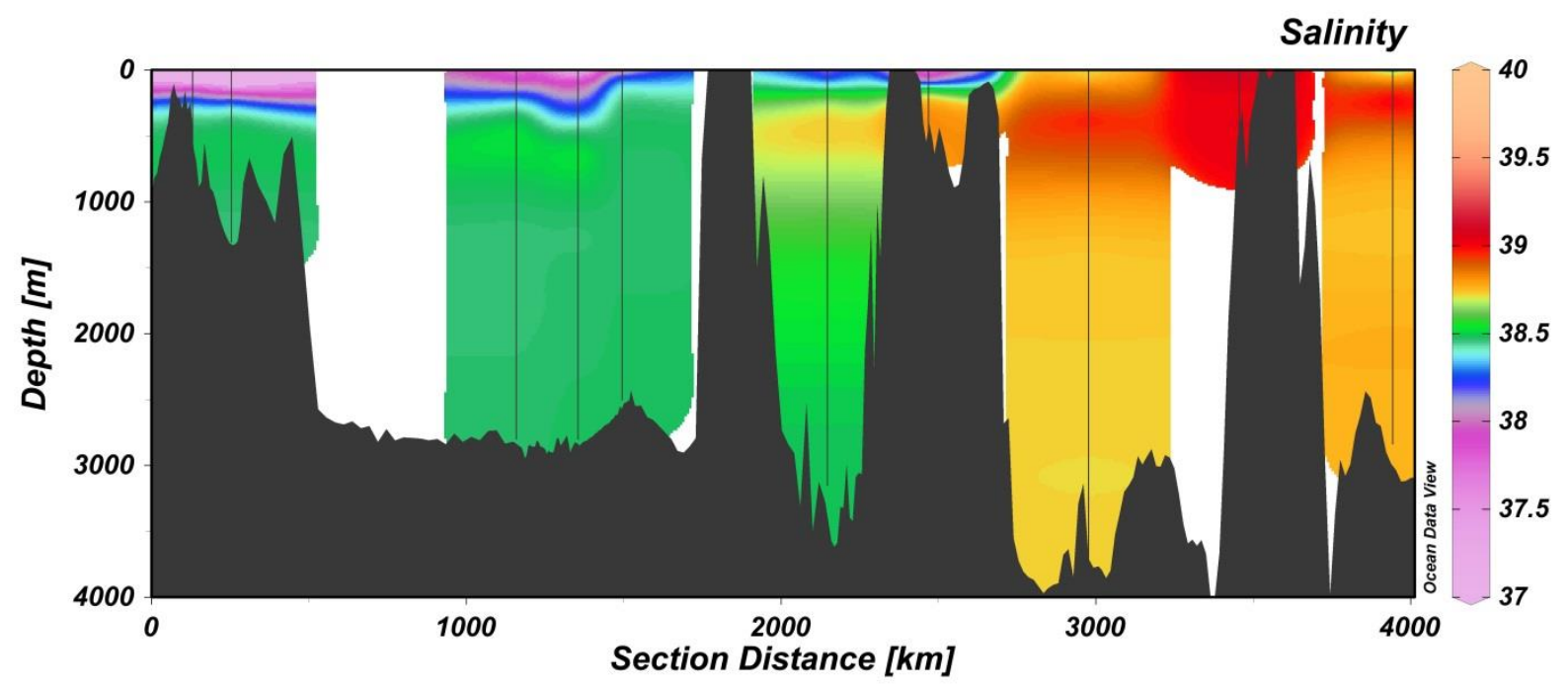

Fig. 2 

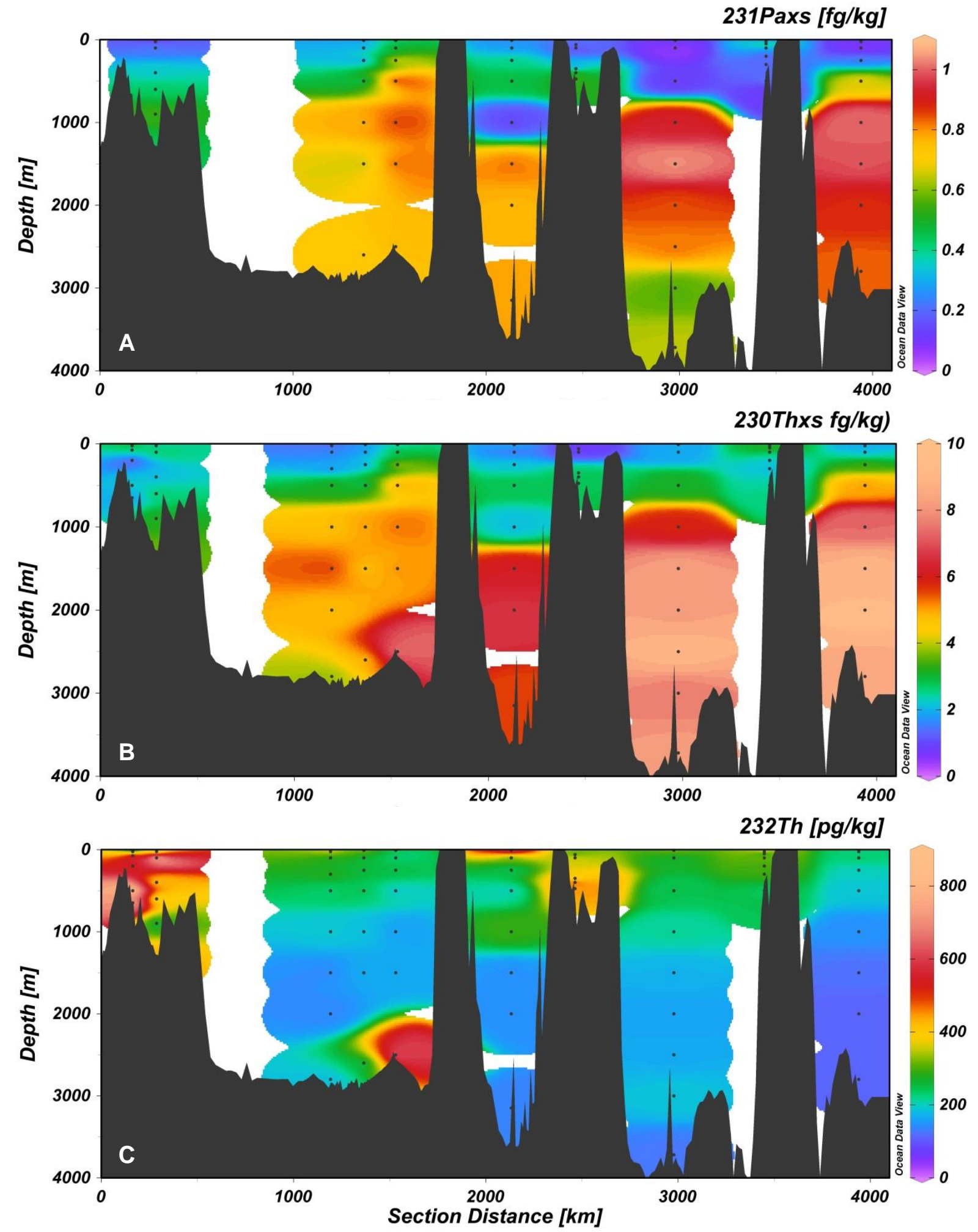

Fig. 3 


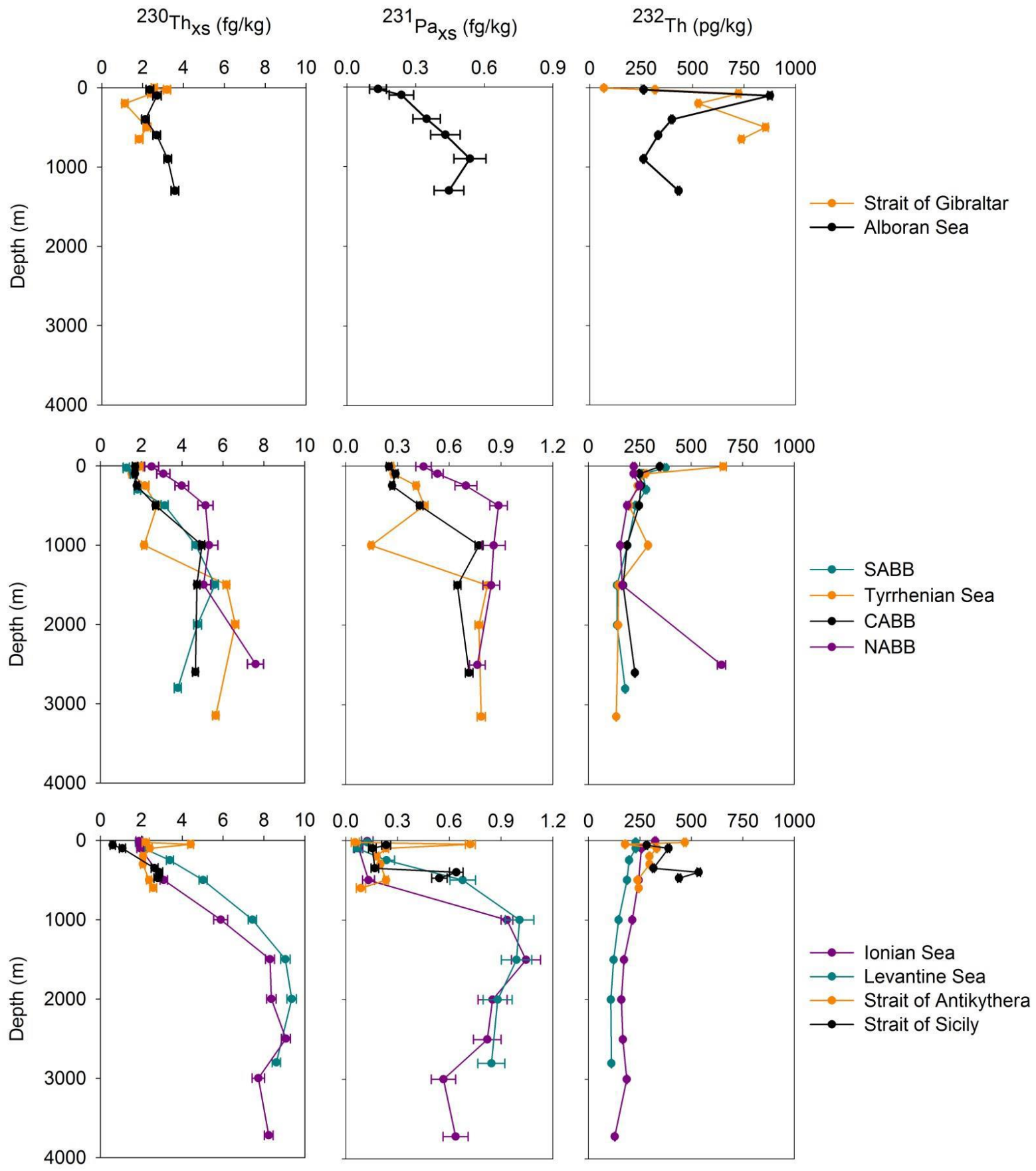

Fig. 4 

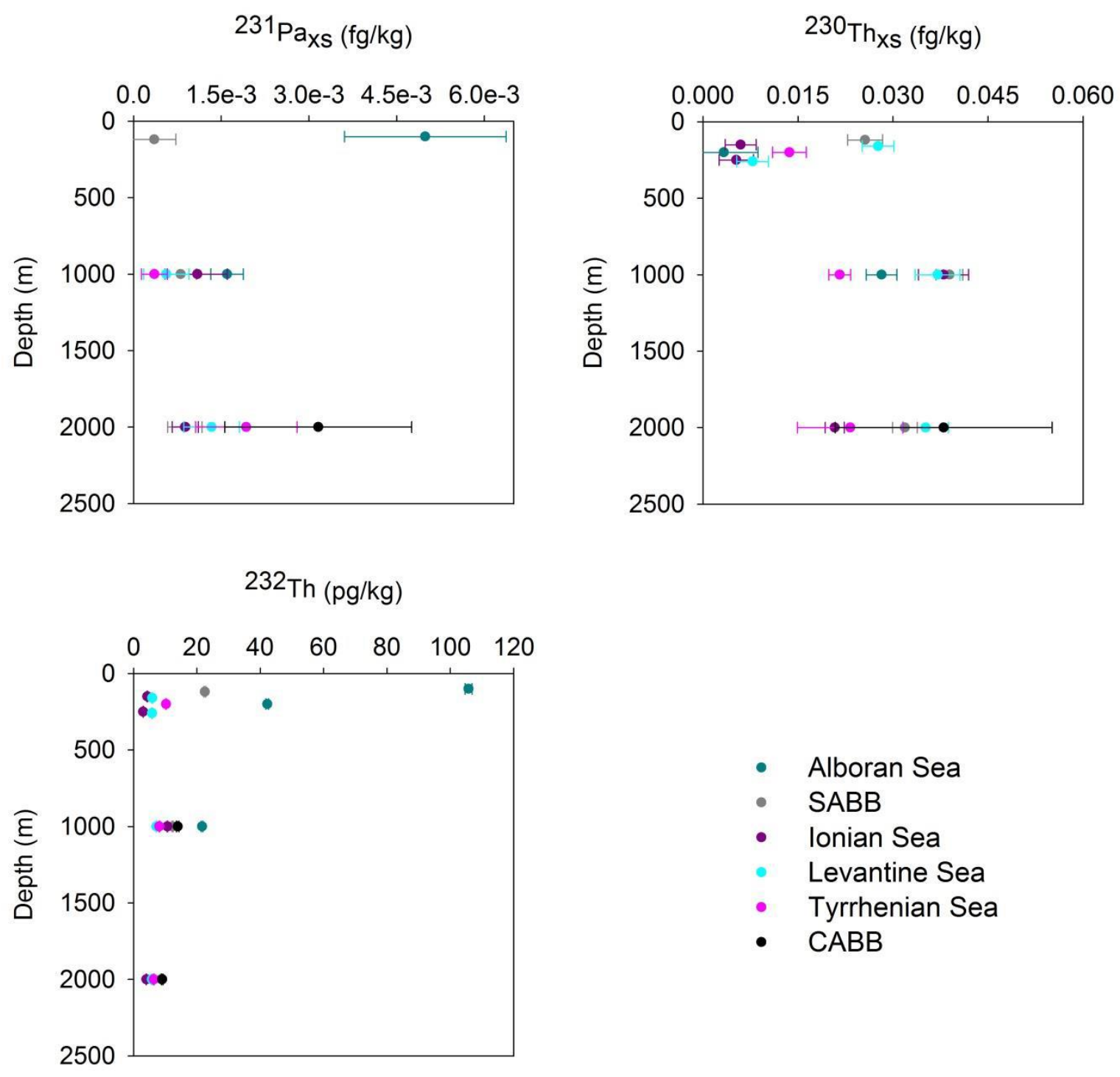

- Alboran Sea

- SABB

- Ionian Sea

- Levantine Sea

- Tyrrhenian Sea

- CABB

Fig. 5 


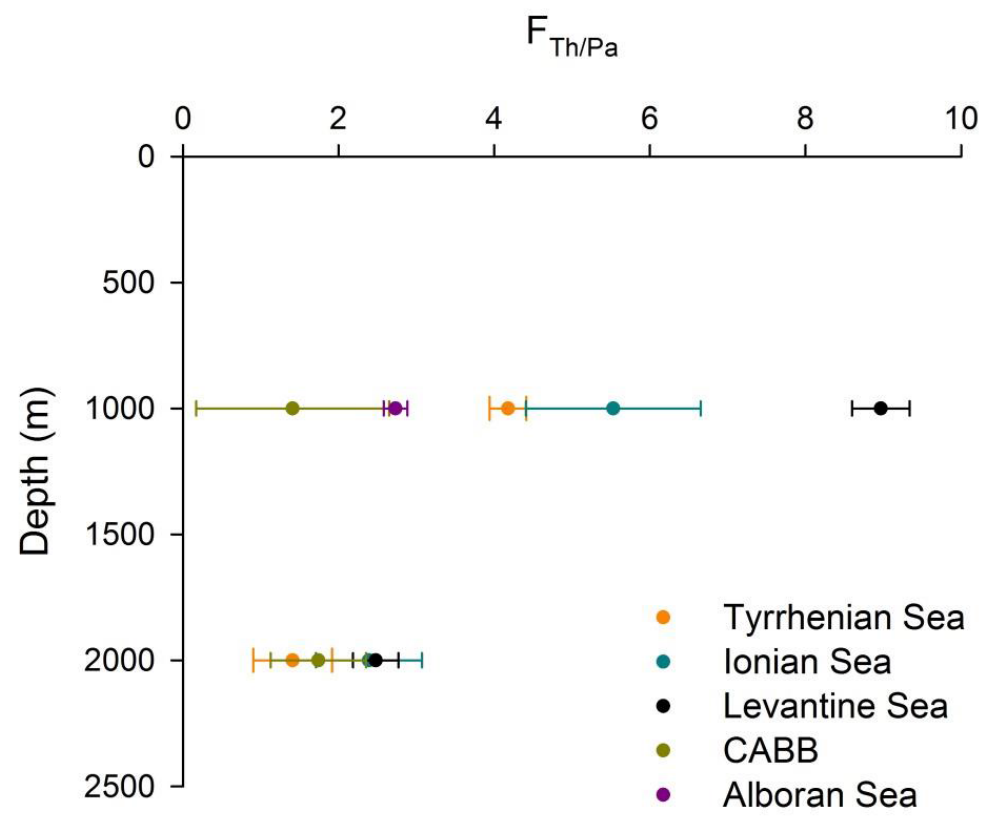

Fig. 6 

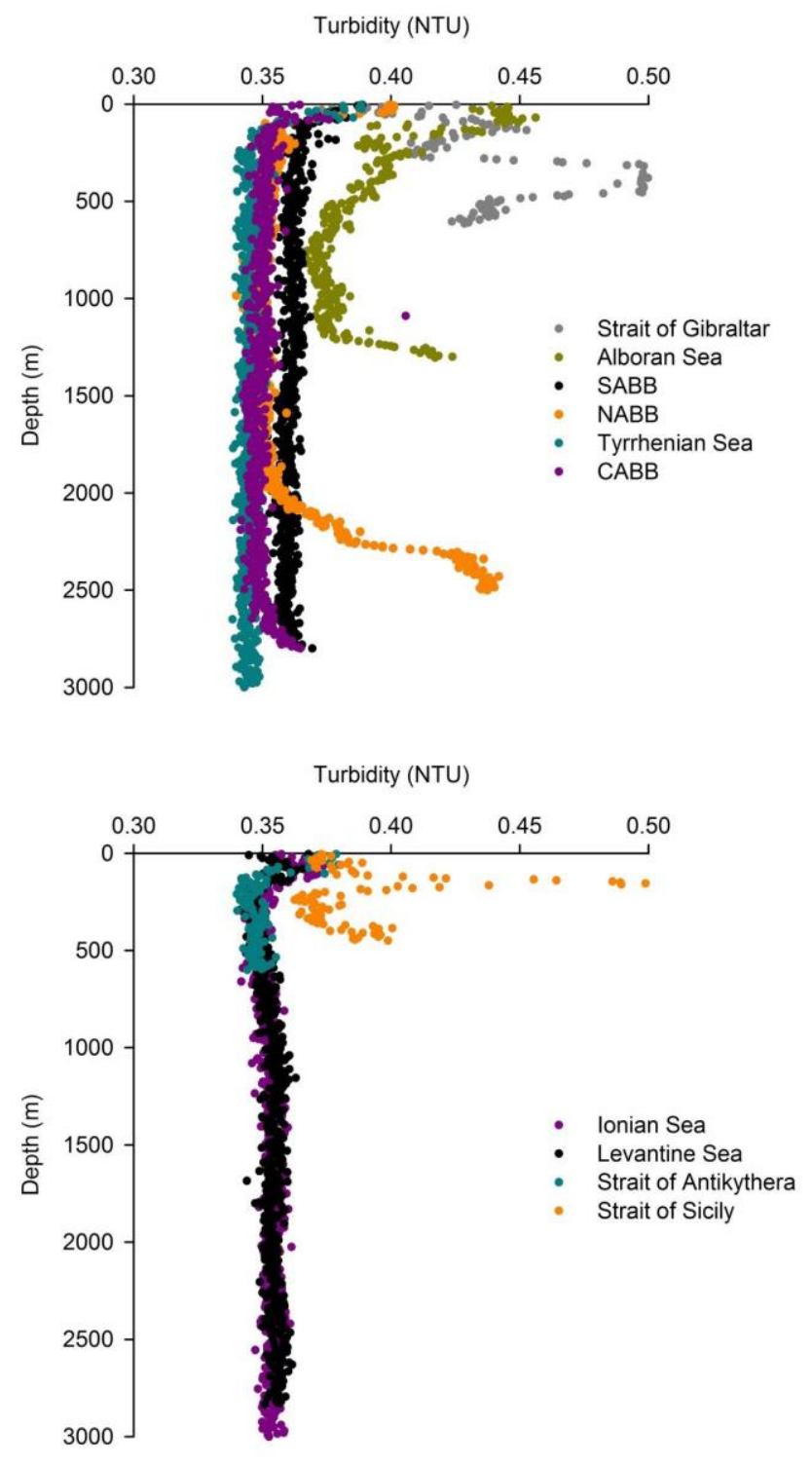

Fig. 7 

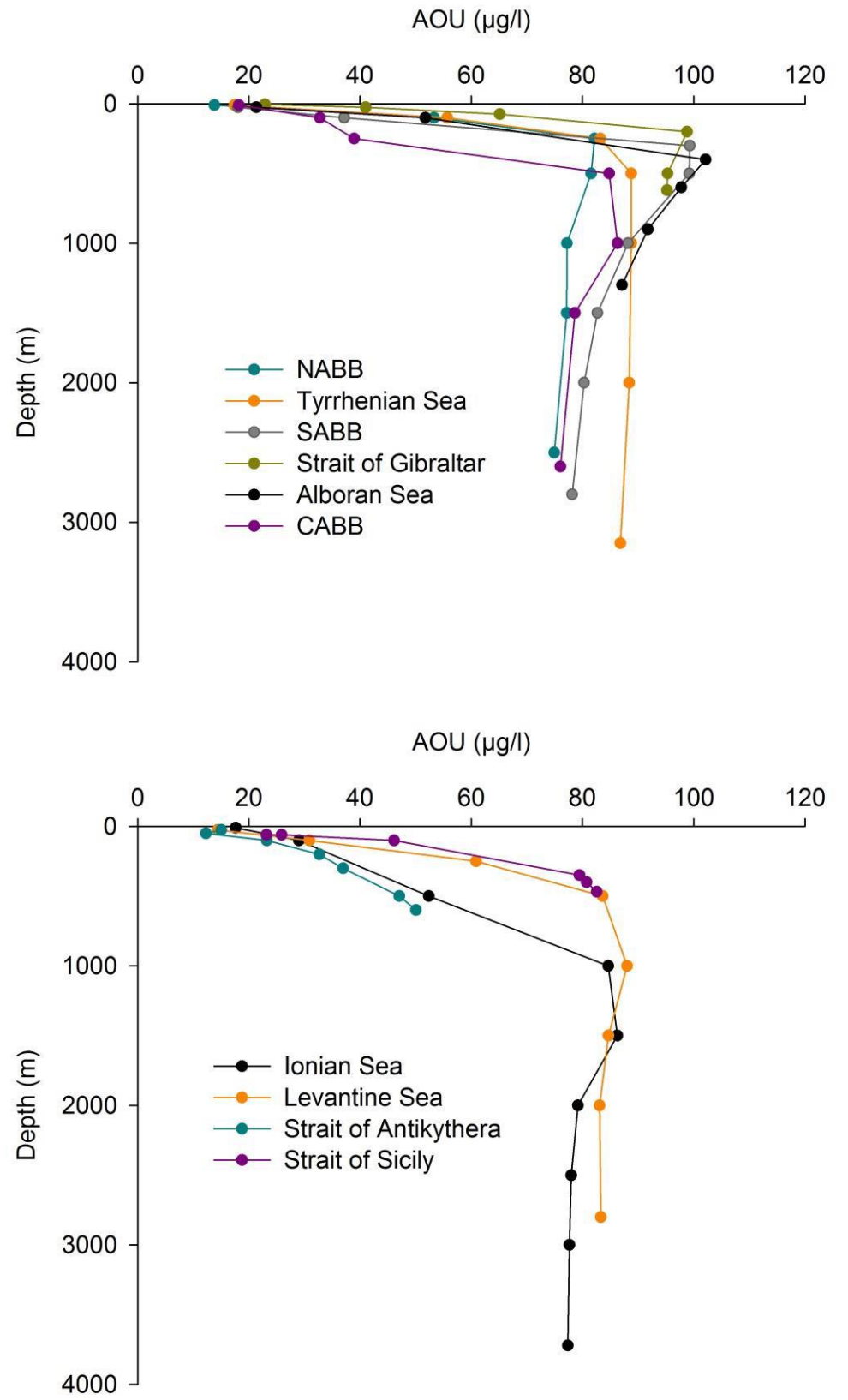

Fig. 8 
Tab. 1

\begin{tabular}{|c|c|c|c|c|c|c|c|c|c|c|}
\hline \multicolumn{7}{|c|}{ Western basin (Box 1) } & \multicolumn{4}{|c|}{ Eastern basin (Box 2) } \\
\hline \multirow{3}{*}{$\begin{array}{l}\text { Inflowing } \\
\text { water }\end{array}$} & \multicolumn{3}{|c|}{ Strait of Gibraltar } & \multicolumn{3}{|c|}{ Strait of Sicily } & \multicolumn{4}{|c|}{ Strait of Sicily } \\
\hline & $\begin{array}{l}{ }^{231} \mathrm{~Pa}_{\mathrm{xs}} \\
(\mathrm{fg} / \mathrm{kg})\end{array}$ & $\begin{array}{l}{ }^{230} \mathrm{Th}_{\mathrm{xs}} \\
(\mathrm{fg} / \mathrm{kg})\end{array}$ & \multirow{2}{*}{$\begin{array}{c}\text { Water flux } \\
(\mathrm{kg} / \mathrm{y})\end{array}$} & $\begin{array}{l}{ }^{231} \mathrm{~Pa}_{\mathrm{xs}} \\
(\mathrm{fg} / \mathrm{kg})\end{array}$ & $\begin{array}{l}{ }^{230} \mathrm{Th}_{\mathrm{xs}} \\
(\mathrm{fg} / \mathrm{kg})\end{array}$ & \multirow{2}{*}{$\begin{array}{c}\begin{array}{c}\text { Water flux } \\
(\mathrm{kg} / \mathrm{y})\end{array} \\
3.9 \times 10^{16}\end{array}$} & \multirow[t]{2}{*}{$\begin{array}{l}\text { Inflowing } \\
\text { water }\end{array}$} & $\begin{array}{l}{ }^{231} \mathrm{~Pa}_{\mathrm{xs}} \\
(\mathrm{fg} / \mathrm{kg})\end{array}$ & $\begin{array}{l}{ }^{230} \mathrm{Th}_{\mathrm{xs}} \\
(\mathrm{fg} / \mathrm{kg})\end{array}$ & \multirow{2}{*}{$\begin{array}{c}\begin{array}{c}\text { Water } \\
\text { flux } \\
(\mathrm{kg} / \mathrm{y})\end{array} \\
4.0 \mathrm{x} \\
10^{16}\end{array}$} \\
\hline & $0.19 \pm 0.04$ & $2.5 \pm 0.20$ & & $0.40 \pm 0.03$ & $2.6 \pm 0.17$ & & & $0.19 \pm 0.02$ & $0.8 \pm 0.14$ & \\
\hline \multirow{3}{*}{$\begin{array}{l}\text { Outflowing } \\
\text { water }\end{array}$} & \multicolumn{3}{|c|}{ Strait of Gibraltar } & \multicolumn{3}{|c|}{ Strait of Sicily } & \multirow{3}{*}{$\begin{array}{l}\text { Outflowing } \\
\text { water }\end{array}$} & \multicolumn{3}{|c|}{ Strait of Sicily } \\
\hline & $\begin{array}{l}{ }^{231} \mathrm{~Pa}_{\mathrm{xs}} \\
(\mathrm{fg} / \mathrm{kg})\end{array}$ & $\begin{array}{l}{ }^{230} \mathrm{Th}_{\mathrm{xs}} \\
(\mathrm{fg} / \mathrm{kg})\end{array}$ & $\begin{array}{c}\text { Water flux } \\
(\mathrm{kg} / \mathrm{y})\end{array}$ & $\begin{array}{l}{ }^{231} \mathrm{~Pa}_{\mathrm{xs}} \\
(\mathrm{fg} / \mathrm{kg})\end{array}$ & $\begin{array}{l}{ }^{230} \mathrm{Th}_{\mathrm{xs}} \\
(\mathrm{fg} / \mathrm{kg})\end{array}$ & $\begin{array}{c}\text { Water flux } \\
(\mathrm{kg} / \mathrm{y})\end{array}$ & & $\begin{array}{l}{ }^{231} \mathrm{~Pa}_{\mathrm{xs}} \\
(\mathrm{fg} / \mathrm{kg})\end{array}$ & $\begin{array}{l}{ }^{230} \mathrm{Th}_{\mathrm{xs}} \\
(\mathrm{fg} / \mathrm{kg})\end{array}$ & $\begin{array}{l}\text { Water } \\
\text { flux } \\
(\mathrm{kg} / \mathrm{y})\end{array}$ \\
\hline & $0.39 \pm 0.07$ & $2.7 \pm 0.18$ & $5.2 \times 10^{16}$ & $0.19 \pm 0.02$ & $0.84 \pm 0.14$ & $4.0 \times 10^{16}$ & & $0.40 \pm 0.02$ & $2.6 \pm 0.17$ & $\begin{array}{l}3.9 x \\
10^{16}\end{array}$ \\
\hline
\end{tabular}

\begin{tabular}{|c|c|c|c|c|c|c|}
\hline \multicolumn{5}{|c|}{ Western basin ${ }^{231} \mathrm{~Pa}_{\mathrm{xs}}$ and ${ }^{230} \mathrm{Th}_{\mathrm{xs}}$ fluxes } & \multicolumn{2}{|c|}{ Eastern basin ${ }^{231} \mathrm{~Pa}_{\mathrm{xs}}$ and ${ }^{230} \mathrm{Th}_{\mathrm{xs}}$ fluxes } \\
\hline & Strait of Sicily & Strait of Gibraltar & net flux & In situ production & net flux & In situ production \\
\hline $\begin{array}{l}{ }^{231} \mathrm{~Pa}_{\mathrm{xs}} \\
(\mathrm{fg} / \mathrm{y})\end{array}$ & & $-1.0 \times 10^{15}$ & $-2.2 \times 10^{15}$ & $3.5 \times 10^{16}$ & $-7.9 \times 10^{15}$ & $5.8 \times 10^{16}$ \\
\hline $\begin{array}{l}{ }^{200} \mathrm{Th}_{\mathrm{xs}} \\
(\mathrm{fg} / \mathrm{y})\end{array}$ & $6.9 \times 10^{16}$ & $-3.3 \times 10^{15}$ & $6.6 \times 10^{16}$ & $8.7 \times 10^{17}$ & $-6.9 \times 10^{16}$ & $1.5 \times 10^{18}$ \\
\hline
\end{tabular}

Volume Box $1=1.4 \times 10^{18} \mathrm{~L}$

Volume Box $2=2.3 \times 10^{18} \mathrm{~L}$ 